\title{
Review \\ Application of Electrospun Nonwoven Fibers in Air Filters
}

\author{
Iman Azarian Borojeni, Grzegorz Gajewski and Reza A. Riahi *
}

check for

updates

Citation: Borojeni, I.A.; Gajewski, G.; Riahi, R.A. Application of Electrospun Nonwoven Fibers in Air Filters. Fibers 2022, 10, 15. https://doi.org/ 10.3390/fib10020015

Academic Editor: Martin J. D. Clift

Received: 31 August 2021

Accepted: 17 November 2021

Published: 8 February 2022

Publisher's Note: MDPI stays neutral with regard to jurisdictional claims in published maps and institutional affiliations.

Copyright: (c) 2022 by the authors. Licensee MDPI, Basel, Switzerland. This article is an open access article distributed under the terms and conditions of the Creative Commons Attribution (CC BY) license (https:// creativecommons.org/licenses/by/ $4.0 /)$.
Department of Mechanical, Automotive and Materials Engineering, University of Windsor, Windsor, ON N9B 3P4, Canada; azarian@uwindsor.ca (I.A.B.); gajewskg@uwindsor.ca (G.G.)

* Correspondence: ariahi@uwindsor.ca

\begin{abstract}
Air filtration has seen a sizable increase in the global market this past year due to the COVID-19 pandemic. Nanofiber nonwoven mats are able to reach certain efficiencies with a lowpressure drop, have a very high surface area to volume ratio, filter out submicron particulates, and can customize the fiber material to better suit its purpose. Although electrospinning nonwoven mats have been very well studied and documented there are not many papers that combine them. This review touches on the various ways to manufacture nonwoven mats for use as an air filter, with an emphasis on electrospinning, the mechanisms by which the fibrous nonwoven air filter stops particles passing through, and ways that the nonwoven mats can be altered by morphology, structure, and material parameters. Metallic, ceramic, and organic nanoparticle coatings, as well as electrospinning solutions with these same materials and their properties and effects of air filtration, are explored.
\end{abstract}

Keywords: electrospinning; nonwoven; air filter; SARS-CoV-2; polymers

\section{Introduction}

Due to the COVID-19 pandemic, the air filter global market saw its largest increase of $6.6 \%$, worth a total of 12.89 billion USD in 2020 [1]. Due to the pandemic, not only are higher efficiency, lower pressure-drop face masks needed, but so are better air filtration systems for hospitals, schools, offices, elevators, public transport, airplanes, etc. It is even suggested that areas with higher pollution and lower wind speeds tend to have a higher infection rate, including indoors, during the SARS-CoV-2 pandemic [2]. As small airborne droplets are seen as a probable third route to COVID infections, proper ventilation, enhanced with filtration, disinfection, and avoiding air recirculation is essential to reduce the transmission rate.

Many techniques for air purification and filtration have been developed. Some of the most common are plasma, ultraviolet (UV), high-efficiency particulate air (HEPA) filters, activated carbon, ionic, electronic, and central air purifiers. Plasma air purification uses a high voltage discharge to make electrons collide with air particles, which create ions and radicals that remove particulates, bacteria and oxidize organic pollutants. However, due to the energy consumptions and the creation of ozone molecules, plasma purifiers are limited in their indoor use [3]. Even with different methods, the HEPA-activated carbon, electronic, and central air purifiers all use some form of the air filter to assist in cleaning the air. HEPA air filters have a most penetrating particle size of 0.15-0.2 micrometers [4], although regarded as great filters they are made to remove particles larger than 0.2 micrometers. This leaves some particles able to pass through them, such as volatile organic compounds (VOC), bacteria, viruses, and mold, with SARS-CoV-2 virus size ranging from 0.02-0.5 micrometer falls within this range [5].

In this paper, air filters made of nonwoven mats are reviewed. Both woven and nonwoven filters exist, each with its advantages and disadvantages. The pore sizes of woven filters are easy to estimate. They are easy to construct for the desired filtration efficiency and are easy to clean. Nonwoven filters have higher permeability, an overall higher filtration efficiency, and no chance of yarn slippage, which is an issue in woven filters. 
Nonwoven filters have also shown the recent trends of being lower cost, an expansion in their applications, better resistance to various temperatures, lower pressure drops at given efficiencies, and more global usage [6].

Nonwoven mats can be manufactured through many processes, including spun bond, melt-blown, or electrospinning. Spun bonded, and melt-blown nonwoven mats both have larger fiber diameters than electrospinning. The spun-bond process yields fiber diameters of 10-35 $\mu \mathrm{m}[7,8]$, and melt-blowing often yields fibers $1-5 \mu \mathrm{m}$ but can be as small as 300 $500 \mathrm{~nm}$ [9]. However, electrospinning can make fibers in a large range of diameters, from 2 micrometers down to a few nanometers [10]. These fiber sizes allow for the filters to filter out smaller particles and other airborne contaminants, such as viruses and bacteria. These nanofibers made through electrospinning also have the added benefit of being electrically charged without the need for a secondary process [11].

In this review paper, the focus will be on nonwoven mats used in air filtration. Different materials for the manufacture of these mats will be covered, as well as processes for cleaning and disinfecting the filters, the fiber morphology in respect to its effect on the efficiency of the nonwoven mat, and the processes in which these nonwoven mats interact with the particles that are being filtered.

\section{Conventional Methods for the Fabrication of Nonwoven Fibrous Air Filters}

\subsection{Fabrication Techniques}

\subsubsection{Spunbond}

The process of spunbond is one of the most popular methods for polymer fiber production. In this method, the polymer is melted in the extrusion section. The molten polymer then travels through a series of filters and pumps to remove any solid particles that can interrupt the process and provide enough pressure for the next step. Afterward, the molten polymer passes through the die (a bank of spinnerets) with a spin-hole of 250-1000 $\mu \mathrm{m}$ to provide continuous molten polymer jets. The jets move across the quench chamber which is cooled down by flowing air. The airflow also stretches the fibers leading to a reduction in diameter of the fibers to $10-35 \mu \mathrm{m}$. The fibers normally collect on a conveyor belt where the nonwoven layer's basis weight can be adjusted by the speed of the belt as well as the throughput of the produced fibers (Figure 1). As the fibers on the belt are loosely bonded together and can easily separate from the formed layer, a thermal, mechanical, or chemical treatment is applied to improve the bonding of the fibers together. Relatively thick fibers $(10-35 \mu \mathrm{m})$ with a wide range of basis weight (typically $10-500 \mathrm{~g} / \mathrm{m}^{2}$ ) can be produced by this method $[7,8]$.

The process enjoys an extremely high production rate and has relatively high energy efficiency because it needs cold air for the downsizing of the fibers [12]. However, controlling the process is not straightforward, and is very sensitive to the processing condition. For example, to produce polyethylene terephthalate (PET) fibers, the moisture level of the pellets should not exceed 20-30 ppm; otherwise, the filaments become broken during the process. The resin should also have excellent viscoelastic properties and be homogeneous to tolerate a $5000 \mathrm{~m} / \mathrm{min}$ production rate. Furthermore, the molten polymer should have very low viscosity to pass through the small spin-hole without building up high pressure. Such requirements narrow the window of polymer selection for the spunbond process. The process is very well established to produce PP and PET fibers, but most of the polymers cannot fulfill its process requirements [8].

Contrary to this, almost all polymers can be processed by the melt-blown technique. Even the fibers of some natural polymers such as starch and cellulose can be produced by this method [13]. The melt-blown process and equipment are similar to spunbond when considering that companies that work on spunbond often prefer to invest in the meltblown method, too, and vice versa [14]. However, these two methods are quite different in detail [8]. 


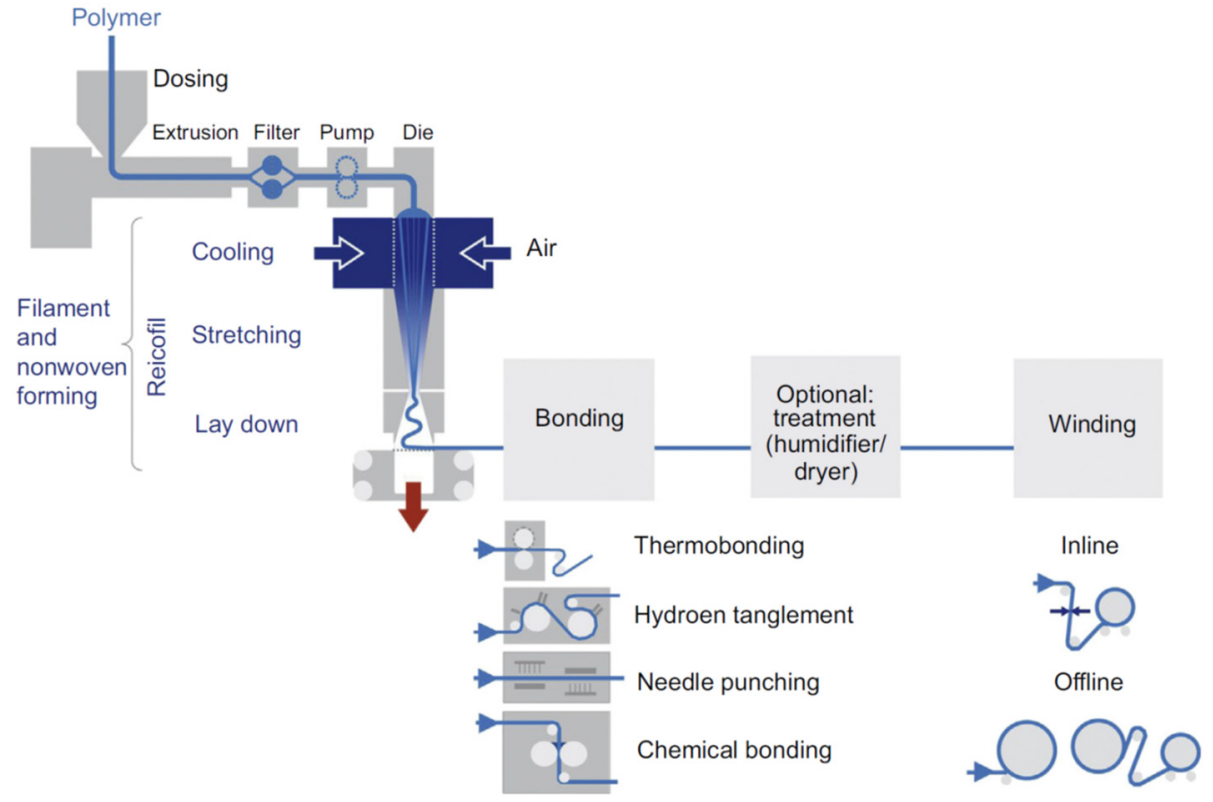

Figure 1. The setup of the spunbond process (Reprinted with permission from [8]. Copyright 2016 Elsevier).

\subsubsection{Melt-Blown}

In the melt-blown process, the molten polymer is provided and passed through a bank of spinnerets in a similar way to the spunbond process. However, instead of the cool air, very hot, high-speed air is blown in the direction of the molten polymer jets (Figure 2). The hot air, whose temperature is close to the melt temperature of the polymer, stretches the jets and downsizes their diameters to $1-5 \mu \mathrm{m}$ in the final product. Applying the high-speed hot air not only reduces the fiber size significantly but also causes the widely distributed range of size in the formed nonwoven layer [8]. Since the filaments are still hot when they are collected on the conveyor belt, they bond together spontaneously; therefore, unlike the spunbond process, no additional treatment for the bonding is required [15]. Although meltblown is typically utilized to produce microfibers, some successful works also reported the production of nanofibers in the range of $300-500 \mathrm{~nm}$ by this method $[9,16,17]$.

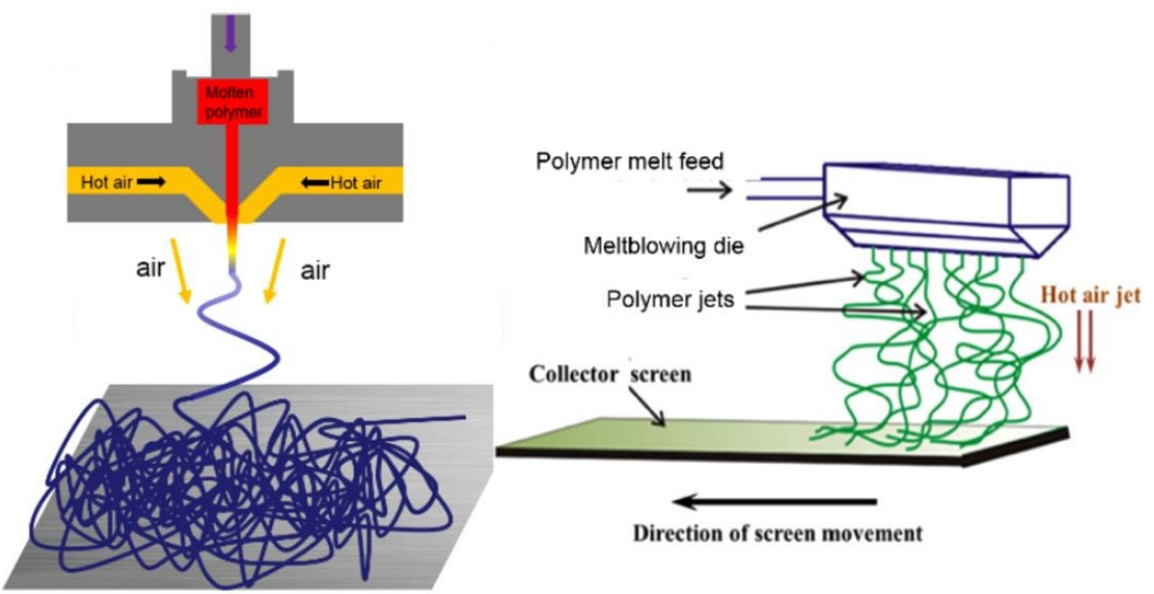

Figure 2. The setup for the melt-blown process (Reprinted with permission from [13]. Copyright 2019 ACS Publications).

Since narrower fibers can be produced by melt-blown techniques, they can be used for the filtration of submicron particles [8]. However, the process is not as energy efficient as the spunbond process due to using hot air for downsizing the fibers [12]. The fibers 
also suffer from poor mechanical strength and low production rate in comparison to the spunbond fibers [7].

\subsection{Applying a Fiber Charge}

Both spunbond and melt-blown fibers are usually needed to charge up for the highperformance filter application to improve the fine particle's capturing efficiency. Methods such as corona discharge [18], triboelectrification [19], or liquid contact [20] can be applied for charging up the filters, which are produced by spunbond or melt-blown techniques.

\subsubsection{Corona Discharge}

In corona discharge, a very high voltage is applied between the electrodes (which usually have an asymmetric shape such as pointy tips) and the filter surface (Figure 3). The corona can be formed in one of two ways: positive corona and negative corona. For the positive corona, the electrons emitted from the electrodes accelerate due to the high electrical field and collide with the air molecules, which remove some electrons from them. The remaining ions that are usually in the form of hydronium ions $\left(\mathrm{H}^{+}\left(\mathrm{H}_{2} \mathrm{O}\right)_{n}\right)$ (provide an air plasma while the separated electrons participate in a chain reaction (in a similar way to the primary electrons) to generate more ions. On the other hand, for producing negative corona, a photoelectron reaction should take place. The released electrons are then absorbed by the air molecules, which usually have $\mathrm{O}_{2}^{-}$bases such as $\mathrm{O}_{2}^{-}\left(\mathrm{H}_{2} \mathrm{O}\right)_{n}$ During the corona formation, a thin layer of both electrons and ions develops at the vicinity of the polymer surface, penetrates it, and traps in the polymer surface. The penetration depth is usually just a few nanometers, but the charges can sometimes move inside the bulk polymer and re-trap. One of the drawbacks of the corona discharge is the oxidation of the polymer surface, leading to the hydrophilicity of the polymer, which should be avoided for better filter performance. Furthermore, the electron injection can deteriorate the surface of the polymer by generating functional and unsaturated groups as well as broken polymer chains, which enhance the charge mobility and reduce the charge trapping ability of the polymer surface, leading to increasing the decaying the generated surface charge. Therefore, sometimes other methods for charging up the polymer surface are recommended [20].

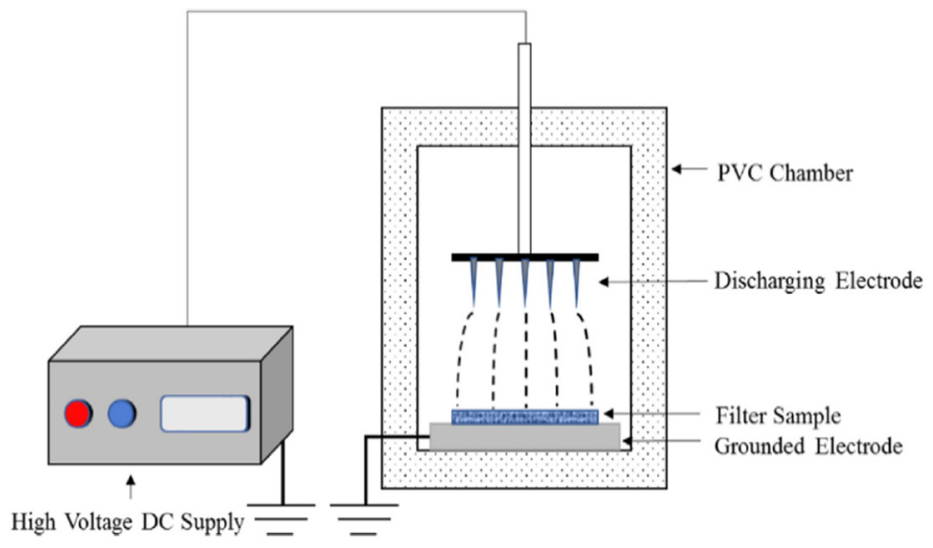

Figure 3. Set up for applying a corona discharge to a filter (Reprinted with permission from [21]. Copyright 2020 Elsevier).

\subsubsection{Triboelectrification}

Tribolectrification is another method for charging the fibers which are developed based on charge generation when two insulators are rubbing against each other. When two insulators are rubbing together, the surface net charge of one becomes positive, and the other one becomes negative. Usually, non-polar polymers such as PP, PAN, and PTFE tend to become negative during this process, while polar polymers such as PA tend to become positive. It is believed the inherent ability of electron-donating and acceptance in insulators (the amount of electron's chemical potential) play a key role in electron transferring, but 
some experiments provided evidence of ion exchange during the triboelectrification process. For charging the PP fibers one of the methods is mixing PP fibers with acrylic and carding $\mathrm{PP}$ to generate the charge. Another triboelectrification is hydroentanglement which is more effective for fluorinated fibers due to their hydrophobicity. A water jet with a pressure of $10-500$ psi or a water droplet stream is applied for charging up the fibers. The generated charge by triboelectrification is very strong, but it is difficult to predict, and controlling the process is not an easy task. Therefore, although the surface chemistry of the polymer does not deteriorate, it is not a very powerful opponent against corona discharge [20].

\subsubsection{Liquid Contact}

One effective method for charge development of the fibers is liquid contact charging. In this technique, the nonwoven fibers pass through a wet sponge-electrode (which is connected to a power supply) and air-blower. Usually, a non-aqueous polar solvent such as methanol, ethanol, or acetone is applied to wet the sponge which is in contact with polymer fibers. The applied field on the sponge makes the fibers charge up (electrophoresis), and the charge will be remained after drying the solvent. The main benefit of this method in comparison with the corona discharge is preserving the surface chemistry of the fibers. Although a relatively high voltage is required for this process, it is far less than the corona discharge, which does not generate air plasma and does not damage the polymer surface [20].

Melt-blown fiber manufacturing is cost-effective for mass production but requires a high start-up cost for the production line. However, the melt-blown process normally yields fibers with diameters in the range of $2-5 \mu \mathrm{m}$, which thicker fibers yield filters with lower efficiency for smaller particles $(0.1-0.5 \mu \mathrm{m})$ [21] and a higher pressure drop [22]. There have been methods that achieve smaller fiber diameters, $0.3-0.5 \mu \mathrm{m}$, but it is difficult to control the parameters [9].

\section{Electrospinning}

Electrospinning is another method for the fabrication of nonwoven filters. In the electrospinning method, a high voltage (usually several $\mathrm{kV}$ ) is applied to a polymer solution (or molten polymer) to produce ultra-fine fibers (from $2 \mu \mathrm{m}$ down to a few nanometers) with a high surface area and surface charges. The fibers can be collected in the form of mats with high porosity and very small pore sizes (Figure 4). Simplicity, cost-effectiveness, ability to control the morphology in different scales, and flexibility to use almost any polymers make it a powerful method for the fabrication of nanofibers [6,23-25].

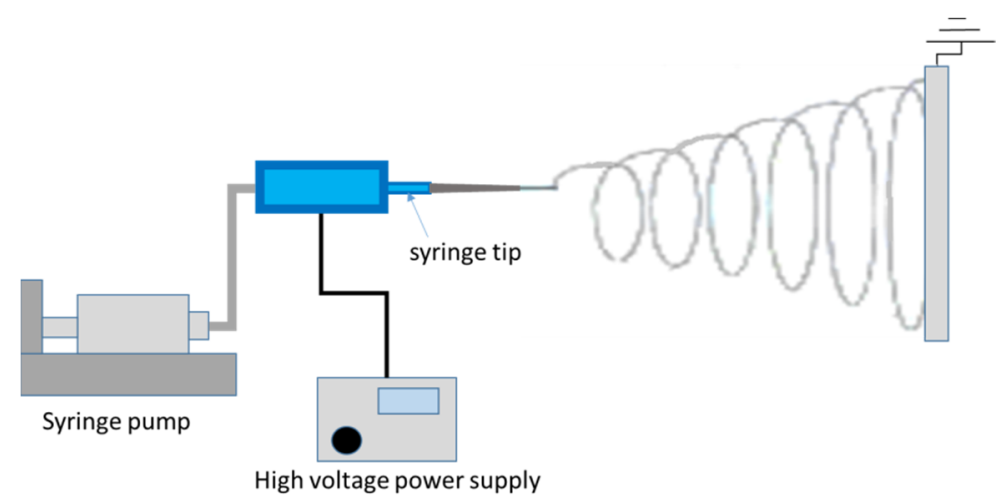

Figure 4. A schematic of the solution-based electrospinning process.

Large surface-to-volume ratio, ability to tailor pore's structure, pore interconnectivity, tunable morphology, and large dust-holding capacity are some of the advantages of electrospun fibers for air filter application [26,27]. Additionally, the fibers become highly charged during the electrospinning process, and a relatively high residual charge remains on the fibers $[27,28]$. Such residual charge can trap small and ultra-small particles without 
blocking the airflow stream. Therefore, the filtering efficiency improves without increasing the pressure drop [26,29-32]. Although charging up of the filters' fiber's is a conventional method for enhancing air filters' performance and is widely used in the production of N95 filters, it needs additional processes such as corona discharge, liquid contact charging electrostatic charging, etc., for charging up the filters. In contrast, the electrospun fibers inherently have high charge accumulation on their surface [20].

A drawback of electrospun filters is their lower than desired mechanical properties [21]. Although the mechanical properties of a single electrospun fiber can be relatively high due to the orientation of the molecular chains during the electrospinning process, the overall mat usually shows lower mechanical strength than a single fiber. The delamination of the mat and disconnection at fiber junctions were considered as the main problems of the low mechanical properties of the electrospun mat [33]. However, with some postprocessing, such as crosslinking, post-fabrication drawing and stretching, solvent welding, heat treatment or annealing, etc. [34], the mechanical properties can be effectively altered to fit the requirements.

One problem that arises in the solution-based electrospinning technique is the retained solvents in the electrospun fibers. Depending on the solution the retained solvent can be hazardous to people, and the nonwoven mats should undergo some process to remove this excess solvent. Although this concern was not usually addressed by the air filter researchers, it is crucial for the biomedical applications of electrospun fibers. Therefore, some post-processing has been proposed by researchers in this field to tackle the residual solvent problem. A. R. D'Amato et al. [35,36] examined four different methods, namely, heating the nanofiber mats, submerging the mats in a lower boiling temperature solvent (ethanol-water bath) for removing the solvents that have an affinity with either liquid and then left to air dry, and placing the mats in a vacuum or desiccator with silica beads at room temperature to evaporate the solvent. They realized submerging the fibers in a $70 \%$ ethanol of deionized water solution was found to be the most effective method of solvent removal, it also sterilized the fibers during treatment [36].

Melt electrospinning could also be a good solution to this problem since it does not require solvents in the polymer melt preparation. However, this process is more complicated than the solution electrospinning method [37,38].

\section{Mechanism of Filtering Process by a Nonwoven Fibrous Air Filter}

There are two approaches for studying the filtering mechanism: steady-state and nonsteady-state. In the former, the accumulation of particles on the filter is neglected; therefore, it is considered that the filtering efficiency and the pressure drop remain constant. Whereas in the latter, the above-mentioned parameters (pressure drop and filter efficiency) change over time due to particle deposition on the filter $[21,26]$. Although a non-steady-state is more realistic, it is too complex for modeling. As a result, the filtering theories usually just focus on steady-state conditions [21].

There are five different mechanisms for capturing particles by nonwoven fibrous filters: interception, inertial impaction, Brownian diffusion, electrostatic, and gravity effect.

\subsection{Interception Mechanism}

If particles are moving very close to the fibers in the filter, they can be captured by the fibers due to Van der Waals's attraction between the particles and the fibers. This mechanism is usually effective for 0.1 to $1 \mu \mathrm{m}$ particles. Reducing the fiber size and increasing the specific surface of the fibers enhance the capturing efficiency of the particles (Figure 5). 


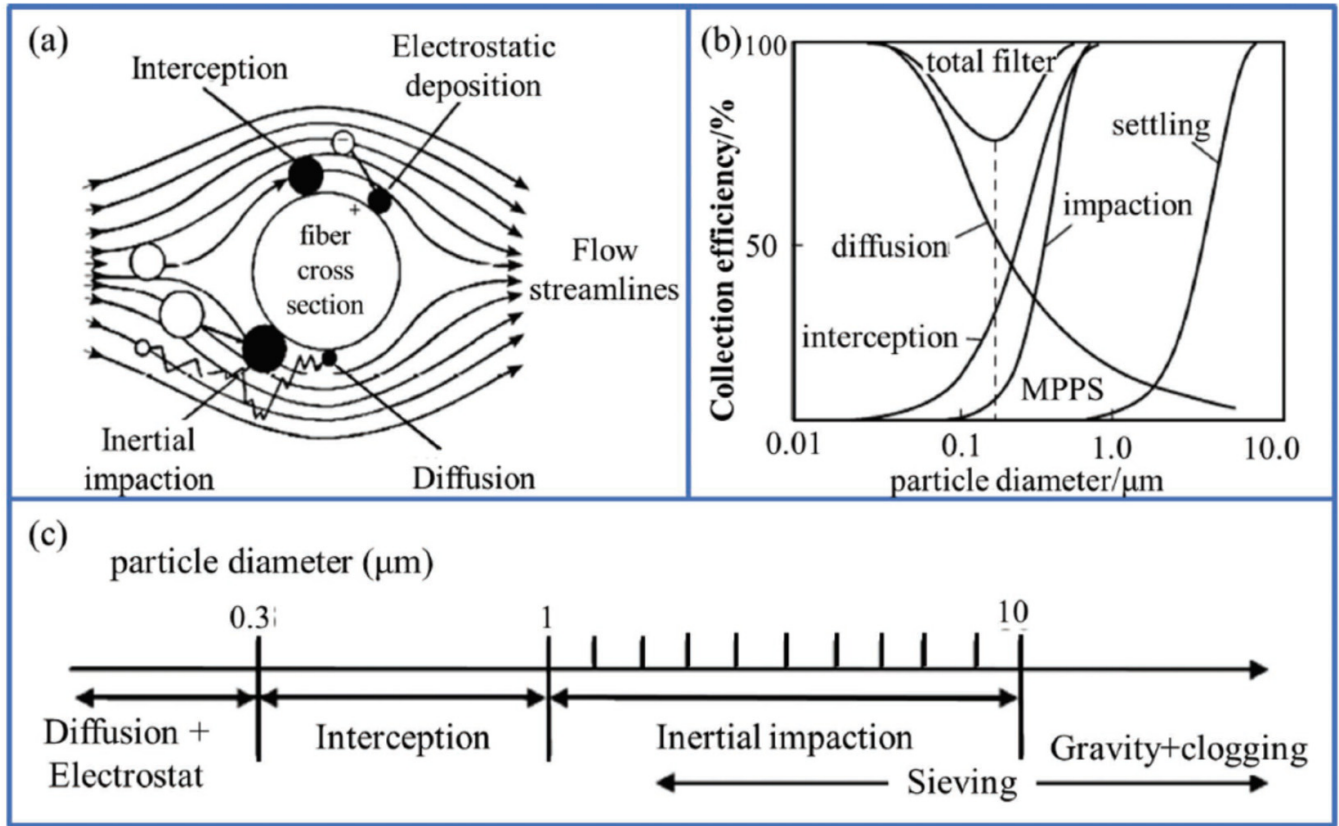

Figure 5. Predominant filtration mechanism depending on particle size(a) the schematic of the main filtration mechanism of a fiber (b) the filtration efficiency for each filtering mechanism as well as the overall efficiency (c) dominant filtration effect based on the particle size (Reprinted with permission from [21]. Copyright 2017 John Wiley \& Sons).

\subsection{Inertial Impaction}

When airflow passes through barriers (fibers), the streamlines of the airflow change their directions near the boundaries of the barriers. If the particles in the streamlines are larger than 0.3 to $1 \mu \mathrm{m}$, they cannot readjust their direction with the streamline easily, and they will be deposited on the fibers. Increasing airflow velocity and the particle size as well as the packing density of the filter, improve inertial impaction for capturing the particles.

\subsection{Diffusion Mechanism}

The Brownian motion can randomly deviate the particles in the airflow from their paths along streamlines which leads to the particles colliding with the fibers and capturing them. Such a mechanism becomes effective when the airflow velocity is low and the particles are very small, 0.1 micrometer [39].

\subsection{Electrostatic Effect Mechanism}

If the particles in the air stream have the opposite charge of the fibers, they will be attracted by the fibers and deposit on them. This mechanism is successful in capturing the submicron particles without increasing the pressure drop.

\subsection{Gravity Effect Mechanism}

For the large particles, gravity can deviate their original path from the airstream, and the particles are absorbed by the fibers. However, this mechanism is not important for high-performance air filters because it can be completely neglected when the size of the particles is less than $0.5 \mu \mathrm{m}$ [21].

\section{Parameters for Filter Performance Evaluation}

The air filter is fastened in an air chamber, covering the entirety of the space. A known airflow is applied in the chamber, and the airflow is measured on either side of the filter to find the pressure drop. Additionally, particulate matter can be applied to the airflow chamber of various sizes, and a photometer can be used to measure the particulate matter 
on the opposite side of the filter to calculate its filtration efficiency [40]. The collection efficiency of an air filter can be defined by the following equation:

$$
\eta=\left(1-\frac{C_{\text {downstream }}}{C_{\text {upstream }}}\right) \times 100
$$

where $\mathrm{C}_{\text {downstream }}$ is the aerosol concentration passing the filter and $\mathrm{C}_{\text {upstream }}$ is the aerosol concentration before passing the filter. The filtering efficiency depends on the size of the aerosols (particles). If particles are very fine or very large, the fibrous filters represent better collective efficiency than the mid-range particles. The mid-range size particles in which the filter shows the least efficiency is called the most penetrating particle size (MPPS), and it has differed from one filter to another. MPPS is usually within a range in which one capturing mechanism switches to another one. For example, the diffusional mechanism mainly works for the particle size less than $0.1 \mu \mathrm{m}$, and the interception mechanism is mostly effective on $0.1-1 \mu \mathrm{m}$. Therefore, particles around $0.1 \mu \mathrm{m}$ may have a higher probability of passing through the filter (Figure 6). In practice, MPPS is usually between 150 to $500 \mathrm{~nm}$, and it is mainly considered $300 \mathrm{~nm}$ [41]. N95 respirators are the air filters that have collecting efficiency for MPPS ( $\eta_{\text {MPPS }}$ ) at least $95 \%$. This standard guarantees that the mask shows high collecting efficiency (more than 95\%) for the smaller or large particles than MPPS [42].

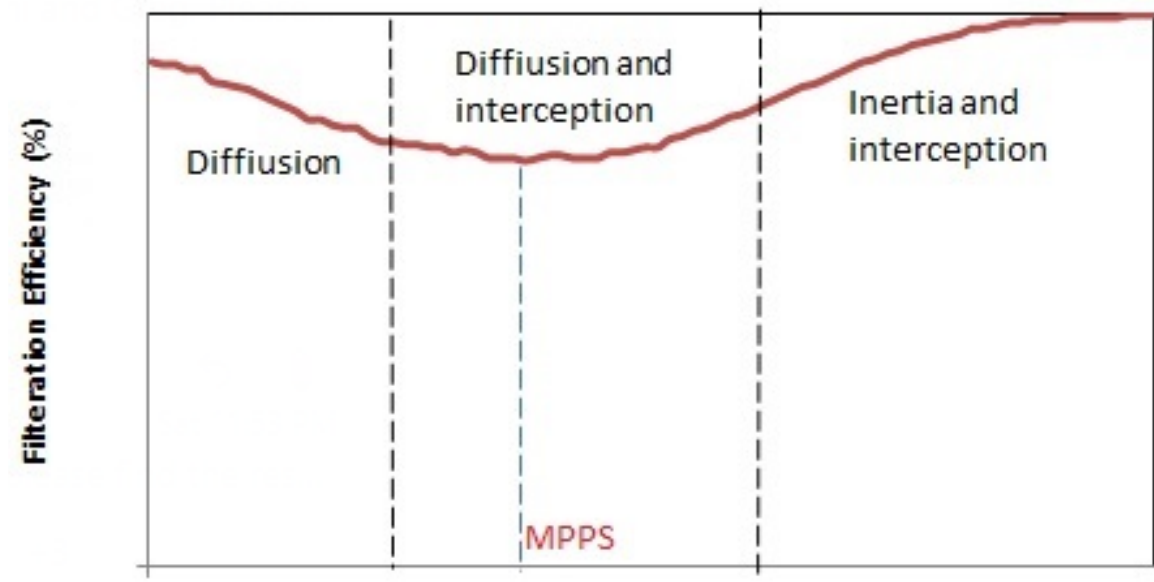

Diameters of Particles (nm)

Figure 6. The efficiency of filter vs. particle diameter in the diffusion and interception regime.

One of the helpful methods for enhancing the efficiency of the air filter is increasing the thickness of the filter or filter basis weight. However, by increasing the basis weight, the pressure drop also increases. In other words, by applying the thick filter, the breathability of the filter is sacrificed. The question is how much pressure drop develops for certain improvement of filtering efficiency by increasing the basis weight., and if we have two different filters (different thickness, material, packing density, etc.), how we can compare them. To answer these questions, quality factor $(\mathrm{QF})$ has been defined as:

$$
\mathrm{QF}=-\frac{\ln (1-\eta)}{\Delta \mathrm{P}}
$$

where $\eta$ is the filtering efficiency and $\Delta \mathrm{P}$ is the pressure drop when the air passes through the filter. Based on the definition, higher QF can be achieved by enhancement filtering efficiency and reduction of the pressure drop. High QF shows better filter performance, which means that by increasing the filter thickness, the impact of a higher filtering efficiency is more than the effect of pressure drop [21]. The challenge is how to improve the filtering efficiency while the pressure drop does not rise considerably, or rather, how to enhance the QF. 
6. The Effect of Morphological, Structural and Materials Parameters on the Performance of the Air Filters

\subsection{Fiber Diameter}

It has been widely reported that reduction of the fiber diameter can improve the filtering efficiency significantly [43,44] due to higher surface area [22]. Moreover, reduction of fiber size enhances the capturing performance for the smaller particles (300 nm or less) [22].

Although a reduction in the size of the fibers to the range of nanofibers can improve the filtering efficiency, especially for the fine aerosols, this strategy can increase the pressure drop of the filter, too [44]. Therefore, some researchers proposed mixing nanofibers and microfibers to provide air filters with high filtering efficiency while maintaining a lowpressure drop value [45]. The pore size of the filter has an inverse effect on the efficiency of the filter, and however, as the pore size decreases, the pressure drop also increases due to the build-up of the cake layer happening more rapidly $[46,47]$. It was found that the tortuosity of the filter does not have a significant relationship to the filtering efficiency, but instead, the tortuosity depends on the particle size [48].

\subsection{Fiber Roughness}

Wang et al. [49] fabricated a hybrid filter by simultaneously spinning plain and composite electrospun nanofibers (plain: polyacrylonitrile (PAN), composite (PAN + silica nanoparticles). It was observed that increasing the surface roughness due to the presence of silica particles improved the filtering efficiency $(99.989 \%)$ at a relatively low-pressure drop $(117 \mathrm{~Pa})$. They concluded that the rough fibers could generate more streamlines because of increasing stagnation regions near the rough fibers. Therefore, the particles from the streamlines and deposition on the fibers became more probable (Figure 7).

(a)
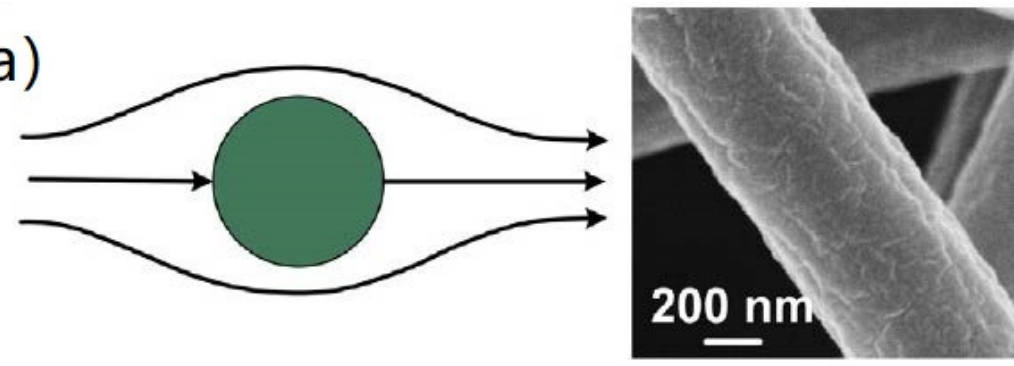

(b)
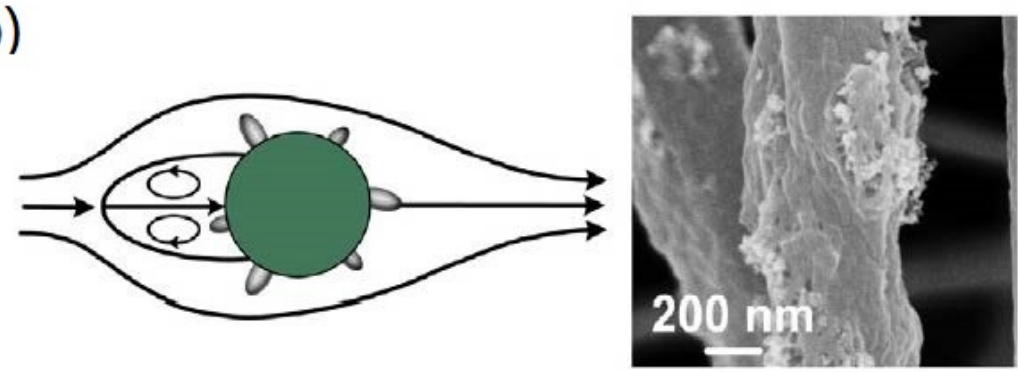

\section{Fiber cross-section}

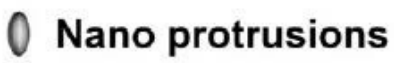

\section{$\rightarrow$ Air flow direction}

Figure 7. Streamlines are forming around circular (a) and non-circular (b) cross-sections of a fiber. (left). SEM image of the fibers (right) (Reprinted with permission from [50]. Copyright 2014 Elsevier).

\subsection{Presence of Beads}

Although for most of the applications usually, beads are preferred to be avoided on the electrospun structure, there have been several reports on the improvement of the filtration 
performance by beads formation on the fibrous structure [50-52]. Wang et al. [50] produced bead on string poly(lactic acid) (PLA) by adjusting the ratio of N, N-dimethylacetamide (DMAC), and Dichloromethane (DCM). They realized when the bead area to the membrane area (BMR) increased and large beads were formed, the beads optimized the packing density of the membrane. As a result, the permeability of the air is enhanced, which means a lower pressure drop could be achieved. When the fiber diameter is decreased and the beads on the fibers are porous, the filtering efficiency was also improved. The optimum filter was shown outstanding filtering efficiency $(99.997 \%)$ with a relatively low-pressure drop (165.3 Pa).

Yun et al. [53] examined the effect of beads on filtration performance. They used polyacrylonitrile (PAN) for the fabrication of beads-free fibers, polymethylmethacrylate (PMMA) for spinning beads on fibers, and PAN-PMMA for producing microsphere and composite structures. For fabrication bead structure, PMMA solution with very high concentration was applied for electrospinning, while for the composite microsphere fibers a periodic electrospinning/electrospray was utilized: one cycle of low concentration PMMA was electrosprayed followed by a cycle of electrospinning of PAN (and this procedure was repeated). Although they obtained excellent quality factors for all produced structures, both beaded nanofibers and composite nanofiber microspheres showed superior quality factors than the plain nanofibers (beaded nanofibers: $0.2351-0.3560 \mathrm{~Pa}^{-1}$, composite: $0.0947-$ $0.2068 \mathrm{~Pa}^{-1}$, and plain: $0.0511-0.1740 \mathrm{~Pa}^{-1}$ ). They suggested that electrospun nanofibers can fuse and bundle together due to their high aspect ratio which may be led to forming high penetrating voids in their structure and decrease the filtration performance. The presence of beads or microspheres reduced the volume fraction and enhanced the effective surface area.

\subsection{Charge Accumulation}

One of the effective methods for improving the filtering efficiency of submicron particles without increasing the pressure drop is by charging the air filter [21]. This is because the morphology of the nanofibers is usually intact by promoting charge accumulation while the particle absorption by electrostatic effect mechanism is boosted. Therefore, air filters are mostly made from electrets: dielectric materials which have a high capacity to retain the electrical charge for a relatively long time $[27,28]$. Polymers such as polypropylene (PP) (which has been widely used for the fabrication of face masks), polyacrylonitrile (PAN), polyvinylidene fluoride (PVDF), polyimide, polyethylene, polycarbonates are exhibited good electret nature [54,55]. It is noteworthy that the residual charge on the electrospun nanofibers can be stored in several ways. One is the orientation of the permanent dipole moments in the polymer or polarization of the mobile charges within the polymer's chains. This can cause dipole orientation which leads to electrostatic polarization in the fibers [28]. It has been reported polymers whose repeating units have higher dipole moments showed superior filtering performance of submicron particles. It was observed that PAN (with repeating unit dipole moment of 3.6D) has better filtering performance than PVP (2.3D), PVA (1.2D), PS (0.7D), and PP (0.6D) [56]. It seemed increasing the dipole moment of the repeating unit enhanced the dipole orientation of the polymer. Therefore, electrostatic polarization was enhanced, and more charge could be retained in the polymer which assisted the filtering performance.

Free charges can also be injected into the fibers during the electrospinning process by different mechanisms such as corona charging. In semi-crystalline polymers, the charges can be trapped in the crystal-amorphous interface and inside of spherulites. In amorphous polymers, charges can be stored in specific structural domains such as heteroatoms and aromatic rings. Therefore, crystallinity, as well as the polymer structure, can affect the capacity of the charge storage, too.

One of the main problems of the electrospun electret air filter is the dissipation of the trapping charges with time, especially under high humidity or temperature condition [41], which deteriorates the filtering efficiency. The temperature was found to the more crucial on dissipating charge (de-trapping) because molecular relaxation of the molecular chains is 
one of the main mechanisms of the charge de-trapping [28]. To address this problem, some additives have been utilized to enhance the number of residual charges of the fibers and preserve it more effectively [41]. The additives usually interact with the polymer chains and restrict their movements, hindering the relaxation process [57].

Figure 8 shows the charge in the electret over time. With only PEI and no nanoparticles used, the electret loses approximately $40 \%$ of its charge within the first hour. The use of nanoparticles was able to increase the amount of time that the electret was able to hold a charge [58]. Wang et al. [59] used PTFE nanoparticles as an additive to enhance the residual charge in the electrospun PVDF nanofibers and reduce the charge dissipation process. The interaction of fluorine atoms of PVDF nanofibers and PTFE nanoparticles provided a strong negative induction effect. The high electronegativity of fluorine atoms in the fluorocarbon segments of PVDF and PTFE produced heavily polarized dipoles even before the fiber formation. Such interactions not only improved the charge accumulation in the nanofibers but also restricted the movement of PVDF polymer chains (Figure 9), which assisted in inhibiting the charge de-trapping process. It was found that adding $0.05 \mathrm{wt} \%$ PTFE increased the charge accumulation and stability while adding more PTFE reduced such effects due to PTFE agglomeration. By further adjustment of the applied electrical field, the surface potential of the nanofibers reached $3.63 \mathrm{kV}$ and decayed only $17.5 \%$ of its original value after $300 \mathrm{~min}$. The final filter exhibited very high filtering efficiency $(99.972 \%)$, low-pressure drop (57 Pa), and excellent quality factor $\left(0.14 \mathrm{~Pa}^{-1}\right)$.

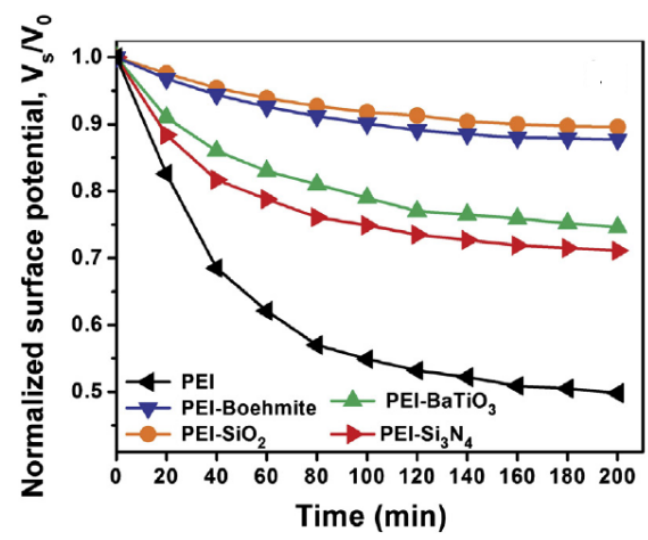

Figure 8. Normalized surface potential vs. time of hybrid membranes at room temperature (Reprinted with permission from [59]. Copyright 2015 Elsevier).

(a)

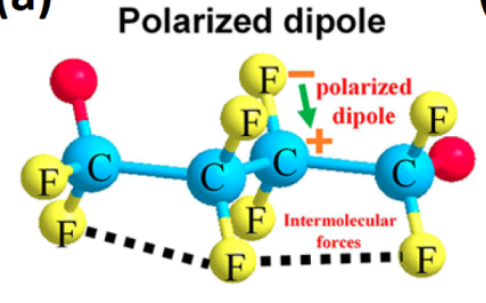

(b) Interfacial polarization

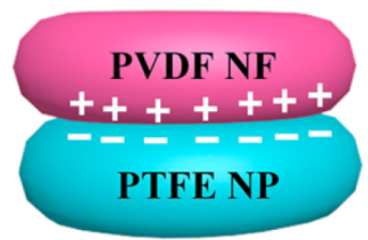

Figure 9. (a)The polarized dipole of the electric charge existing in PVDF nanofibers that contain PTFE nanoparticles. (b) the interfacial concentration of the interaction between PVDF NF and PTFE NP (Reprinted with permission from [59]. Copyright 2016 ACS Publications).

\subsection{Hydrophobicity}

Hydrophobicity is one of the key parameters for selecting the materials for air filters. Increasing the hydrophobicity of a polymer air filter reduces the risk of condensing water on the filter's pores [60]. The presence of water can also deteriorate the performance of the air filter by interaction with the chemical functional groups of the filters [58]. Furthermore, condensation of a thin layer on the surface of the air filter decreases the resistivity of the 
filter because water (even distilled water) has higher conductivity in comparison with electret polymers. Therefore, absorption of water on the polymer surface increases the chance of discharging the stored surface charge of the electret air filter. As a result, not only the resistivity of the polymer is an important factor for selecting material for air filters, but also the capability of repealing moisture should be considered $[19,20]$. For example, polypropylene (PP) has been considered as a good candidate for air filters not just because of its low cost [56], high durability, and electrical resistivity, but its relatively high hydrophobicity was a crucial factor for this purpose $[4,20,61]$.

Besides selecting materials, some researchers have tried to devise electrospun nanocomposite filters to achieve superhydrophobicity for improving the performance of the air filter and sometimes achieving better self-cleaning capability [62]. Li et al. [58] fabricated electrospun nano-composite air filter by co-electrospinning of polyetherimide (PEI) and different nanoparticles; namely, Boehmite, $\mathrm{SiO}_{2}, \mathrm{Si}_{3} \mathrm{~N}_{4}$, and $\mathrm{BaTiO}_{3}$. They realized the $\mathrm{PEI}_{-} \mathrm{SiO}_{2}$ filter has a higher quality factor $\left(0.2522 \mathrm{~Pa}^{-1}\right)$ and long-time charge stability. Additionally, the water contact angle was enhanced from $126^{\circ}$ to $152^{\circ}$ by increasing $\mathrm{SiO}_{2}$ concentration from 0 to $6 \%$. Further increase of $\mathrm{SiO}_{2}$ concentration deteriorated the filtering efficiency as well as the water contact angle due to partial agglomeration of $\mathrm{SiO}_{2}$. Testing with graphite powder also revealed the superior self-cleaning of $\mathrm{PEI}-6 \% \mathrm{SiO}_{2}$ with respect to polypropylene (PP). Furthermore, due to the high dipole orientation of $\mathrm{SiO}_{2}$ and PEI, the filter preserved its remarkable performance even after heat treatment at $200{ }^{\circ} \mathrm{C}$ for $30 \mathrm{~min}$ (filtering efficiency was $99.992 \%$ and pressure drop was 59.5-60.8 Pa). This capability can be useful for sterilizing and reusing air filters during the shortage [63].

\subsection{Stack Structure}

It has been widely reported that using a multilayer structure instead of one thick electrospun layer can reduce the pressure drop of the air filter significantly when the other parameters (basis weight and total thickness) remain constant, resulting in a higher quality factor [43,49,64-67]. Leung et al. [44] coated nonwoven substrates with electrospun PEO nanofibers. While the substrate was made of thick fibers (mean fiber diameter: $14.7 \mu \mathrm{m})$, the PEO electrospun fibers were made of nanofibers (mean fiber diameter: $208 \mathrm{~nm}$ ). It should be mentioned that the substrate caused a small rise in the pressure drop $(1.39 \mathrm{~Pa})$. By stacking up and controlling the electrospinning duration, they were able to make multi-layered and mono-layered air filters with almost the same basis weight.

They realized that at constant basis weight and similar efficiency, far lower pressure drop could be achieved for the multi-layered structure. For example, under the same basis weight when twelve layers were applied, the pressure drop decreased 93.12 Pa while the filtering efficiency slightly reduced from $91.37 \%$ to $82.60 \%$ [44]. They concluded that since the multi-layering modified the packing density and thickness under the same basis weight, the pressure drop could be decreased.

\section{Electrospinning Techniques for Making Air Filters}

\subsection{Single Component Polymer Air Filters}

The first report of using electrospun nanofibers for air filtration is in the early 1980s [21]. Since then, numerous works have been published in this field. Polymers such as PAN, PVA, PA6, PA66, PU, PSU, PVDF, etc. have been used for the fabrication of air filters by electrospinning successfully. While PVDF has been selected for its inherent hydrophobicity [65,66], PAN and PA6 are attractive for their robustness [26] and long lifespan [22]. For example, an electrospun PAN filter can be used in a hazardous area for $100 \mathrm{~h}$ with 95-100\% efficiency [56].

The electrospun air filters are usually deposited on a porous substrate to facilitate the handling [44]. Therefore, the term single component mostly means just one polymer without additive is deposited on a substrate. Because such filters are made by only one polymer, controlling the electrospinning process is easier, making it more attractive for largescale production. The main advantage of such membranes is not only a simpler production 
route but also recyclability. The electrospun air filter can use recycled material and itself be recycled easily by dissolving the filter in an appropriate solvent. Then the polymer can be extracted from the solution and used for electrospinning air filter again [22,52].

\subsection{Multi-Component Air Filters}

Zhao et al. [68] reported making a hybrid multi-layered polymer composite air filter by electrospinning to improve the moisture-vapor transition rate (MVTR) and cleanability of the air filter. They suggested four criteria to achieve their goal: (1) the air filter should contain both hydrophilic and hydrophobic fibers to prevent increasing pressure drop due to water condensation (the role of hydrophobic fibers) and improve MVTR (the role of hydrophilic fibers), (2) hydrophilic groups of the hydrophobic fibers should be on the surface of the fibers to absorb the moisture effectively, (3) the air filter should have a gradient structure to provide an appropriate driving force for the water removal, (4) the air filter should be strong enough to go through the cleaning process without sustaining damage that affects its efficiency $[61,69]$.

They added $\mathrm{SiO}_{2}$ nanoparticles with PAN to make hydrophilic composite fibers. PVDF was also applied to produce hydrophobic fibers. They fabricated a mixture of hydrophilic (PAN-SiO 2 )-hydrophobic (PVDF) fibers by multi-nozzle electrospinning to provide a hybrid layer and sandwich it between hydrophobic and hydrophilic electrospun layers. The final structure was a gradient composite fibrous membrane (Figure 10). Such gradient structure can transport water from the face side and enhance the breathability of the respirator [68].

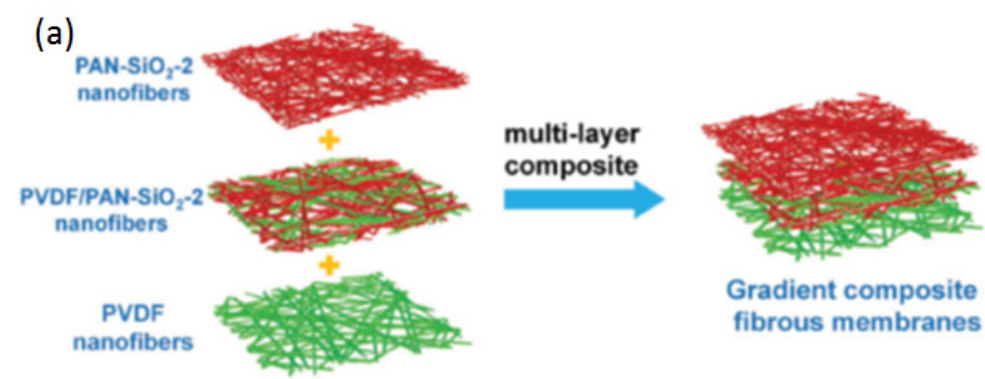

(b)

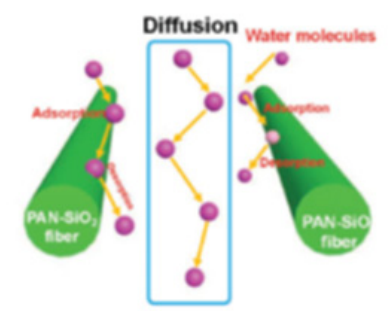

Figure 10. Schematic of the fabrication process, structure, and the interaction with the water molecules (a) the stacking structure of the composite air filter, (b) the mechanism of transferring water molecules (Reprinted with permission from [60]. Copyright 2017 John Wiley \& Sons).

They realized by increasing $\mathrm{SiO}_{2}$ concentration from 0.5 to $2 \mathrm{wt} \%$, the diameter of PAN-SiO 2 nanofibers was decreased, and the wicking rate was enhanced from around $2.4 \mathrm{~cm} / \mathrm{s}$ to $3.5 \mathrm{~cm} / \mathrm{s}$. Although a further increase of $\mathrm{SiO}_{2}$ concentration to $5 \%$ improved the wicking rate to around $4.5 \mathrm{~cm} / \mathrm{s}$, the size of the composite PAN-SiO 2 nanofibers was increased due to the partial agglomeration of $\mathrm{SiO}_{2}$. Therefore, they kept a $2 \mathrm{wt} \% \mathrm{SiO}_{2}$ concentration for the rest of their experiments. The gradient air filter represented an outstanding performance with high filtering efficiency $(99.99 \%)$, relatively low-pressure drop (86 Pa), and high MVTR $\left(13,612 \mathrm{gm}^{-2} \mathrm{~d}^{-1}\right)$. They can also preserve their filtering efficiency for a long time (Figure 11a). The only problem with the air filter was increasing the pressure drop because of clogging the PM2.5 during the field test period in comparison with the commercial one (Figure $11 \mathrm{~b}, \mathrm{~d}$ ). Although they did not mention the reason for the 
clogging in their work, the hydrophilic fibers $\left(\mathrm{PAN}-\mathrm{SiO}_{2}\right)$ might be enhanced by attaching PM2.5 in the way of forming large particles which could clog the filter [68].

(a)
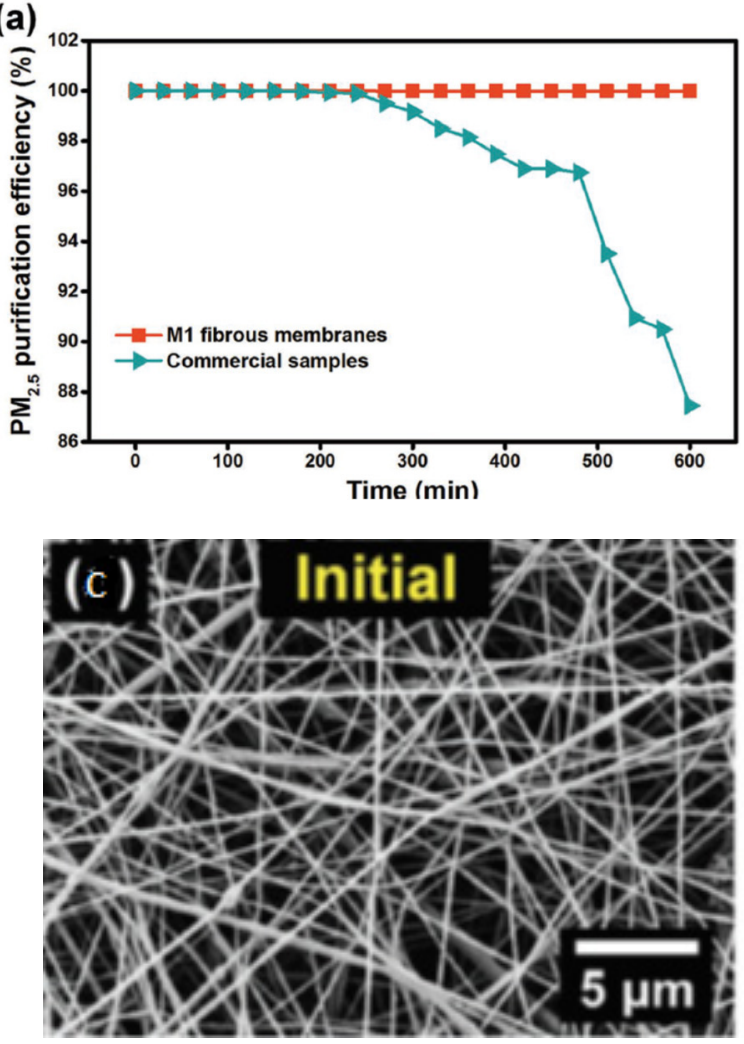

(b)
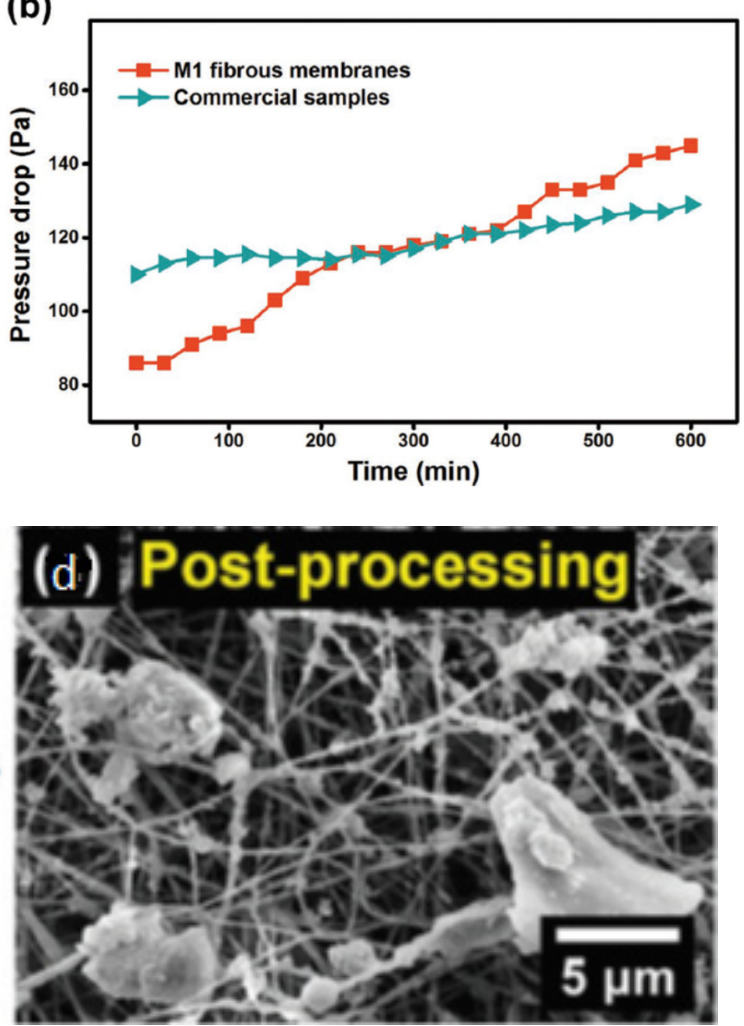

Figure 11. Filtering performance $(\mathbf{a}, \mathbf{b})$ and SEM micrographs of the multi-layered PVDF/PAN-SiO 2 air filter (c,d); (a) comparison between the filtering efficiency of the electrospun multi-layered air-filter and the commercial one (b) comparison between the pressure drop of the electrospun multi-layered air-filter and the commercial one (c) initial fibrous air-filter, (d) after treatment (filter testing) with PM2.5 particles (Reprinted with permission from [60]. Copyright 2017 John Wiley \& Sons).

\subsection{Nanonets}

A net structure produced during the electrospinning process with very fine interconnected fibers (mostly $\sim 20 \mathrm{~nm}$ ) and a small opening (usually $<100 \mathrm{~nm}$ ) is receiving a lot of attention recently, and it seems it has a great potential application in the air filter field [41]. This structure that is called "electrospinning/netting" (ESN), "nano-fiber/net" (NFN), or just nanonet, was observed for the first time by Ding et al. in 2004 when they attempted to electrospin Polyamide 6 (PA-6), calling it "fishnet-like nanonet." However, they did not publish their discovery till 2006 when a similar result has been achieved on Polyacrylic acid (PAA). Since then, fabrication of NFN from a large variety of polymers such as polyamide-6 (PA-6), polyacrylic acid (PAA), polyvinyl alcohol (PVA), polyurethane (PU), poly(trimethylene terephthalate) (PTT), chitosan (CS), Gelatin, Silk have been reported successfully although the mechanism of NFN formation is not clear yet. The most acceptable mechanism is phase separation of charged droplets [70].

Usually during the electrospinning process, if the electrospinning parameters are not well adjusted, the Taylor cone will not be fully stable and both electrospinning/electrospraying can be taken place [24], which has been called the formation of unspun droplets [71], parasite electrospraying [28], or micro-sized charged droplet formation [70]. Applying a high electrical field to the highly charged droplets ejected from the Taylor cone as well as the drag force between the surrounding air and the charged droplets can deform them to the small liquid films (Figure 12). The Coulombic repulsion due to the high accumulated surface charge on the droplets overcame the surface tension and viscoelastic forces leading 
to expanding more film, which in turn generated more drag and more deformation. The transformation of the droplets to the large disk-like films increases the drying rate, which makes phase separation of the polymer-rich and solvent-rich domains. By evaporation, the solvent-rich domains empty parts of the net form while the polymer-rich becomes the nanofibers of the NFN [70].

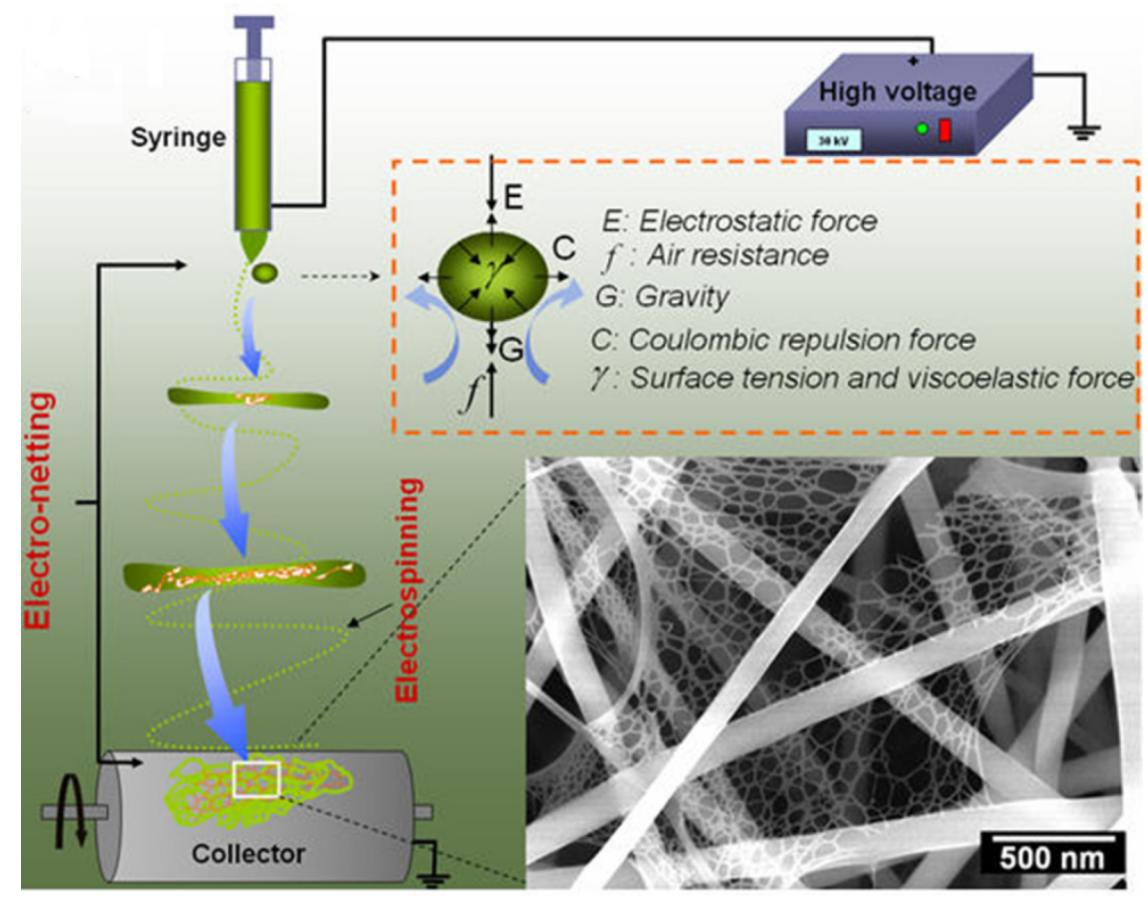

Figure 12. Schematic of possible nanonet formation mechanisms during electrospinning, the forces acting on the droplets, and an SEM image of the fibers and nets formed (Reprinted with permission from [71]. Copyright 2013 Elsevier).

This theory successfully explains why the electrospun fibers and nanonets can be detected in the microstructure simultaneously and why nanonets do not cover the whole microstructure. However, this theory cannot explain the coherency of the nanonet with the other fibers in the way they seemed to branch from the electrospun fibers [72]. A strong hydrogen bond between nylon-6 and methoxy poly(ethylene glycol) (MPEG) oligomers has also been reported, and it was observed the amount of nanonet formation was related to the concentration of MPEG). Again, it is hard to explain this phenomenon by the phase separation theory [73]. Therefore, other theories such as "ions initiated splitting up of the electrospun fiber", "intermolecular hydrogen bonding", and "intertwine among branching jets" have been proposed [70]. However, the "phase separation of charged droplets" is still very popular among researchers, and they usually use it to explain their results.

Production of nanonet is not as straightforward as electrospun fibers. Nanonets just form at certain electrospinning conditions such as very high applied voltage and using a very highly conductive solution. However, tuning the electrospinning parameters does not guarantee the formation of nanonets. In other words, if a polymer is electrospinnable, it does not mean nanonets can also be produced from this polymer even with controlling the electrospinning conditions precisely. When it becomes possible to produce nanonets from a polymer, the next step is controlling the nanonet microstructure by adjustment of NFN parameters. Usually, the diameter of the fibers in the net, opening (pore-width), coverage rate, and density (arrange density in a plan and stacking density) can be controlled by tailoring the NFN condition [70,74].

It is noteworthy that the parameters affected in the nanonet formation have a relatively narrow range for variation, and beyond the range, the formation of nanonets could be 
impeded. For example, the nanonet formation is normally promoted by increasing the conductivity of the solution. In other words, the coverage rate is enhanced by raising the conductivity. For PA6, it was observed that although the addition of salt to the solution caused nanonet formation when the concentration of salt increased from $1.5 \mathrm{wt} \%$ to $2.5 \mathrm{wt} \%$, the nanonets disappeared from the microstructure and instead, porous micro-balls emerged among the nanofibers [72].

Offering extremely small fibers in the structure of nanonets makes them attractive for the air filter application because they exhibit very high filtering efficiency [75-77]. The ability to make very lightweight air filters [58] with high dust holding capacity [26] are desirable properties for this application. Additionally, the ability to control the coverage rate and stacking density of multi-layered nanonets provides the chance to make a balance between improvement of filtering efficiency and increasing the pressure drop. However, the pressure drop of the fabricated air filter by NFN has still been, in most cases, high (usually more than $100 \mathrm{~Pa}$ ) [26].

\section{Antimicrobial Air Filter}

The application of antimicrobial membranes is more developed for water treatment membranes. Since they are in the water micro-organisms can grow on them to form biofilms which may cover the membrane surface (Figure 13) and reduce their functionality as well as increase the pressure drop of the membranes leading to raising the operational cost [78]. Therefore, some techniques which have been used for the antimicrobial water treatment application were utilized for the air filters, too, or they have potential applications for producing antimicrobial air filters.

In the air filter field, the accumulation of pathogens on the membranes can cause a secondary bio-aerosol hazardous source that might infect the user, which can be avoided (at least to some extend) if the air filter shows antimicrobial properties [79]. Additionally, antimicrobial air filters can improve the capturing efficiency of pathogens, which enhances the protection level against hazardous micro-organisms [80,81].

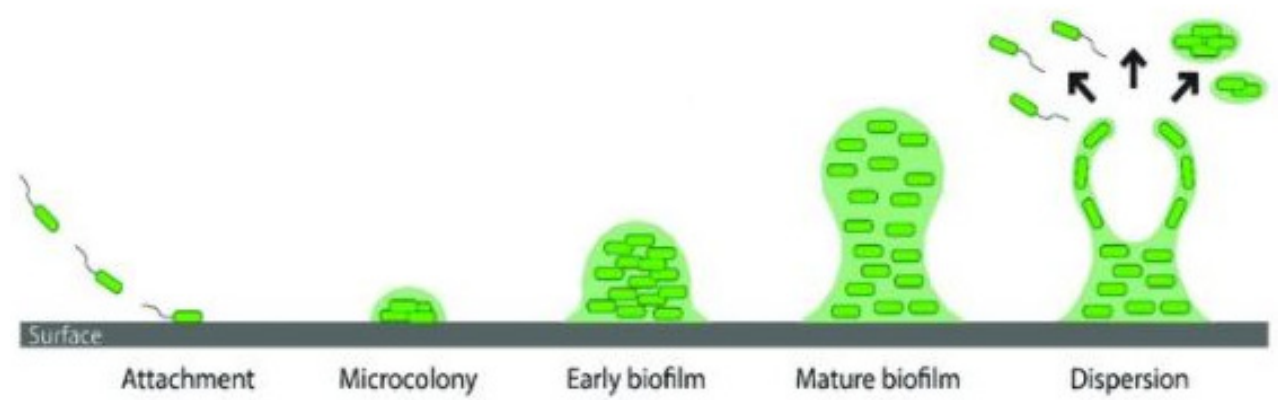

Figure 13. Stages of biofilm formation [82].

Antimicrobial air filters mostly inhibit the pathogens by two mechanisms: (1) Capturing them by the electrostatic interaction between the antimicrobial agent and the microorganism membrane's charge. Ionization of prototropic groups such as carboxyl and amino groups usually develops a net negative charge at the surface of the micro-organisms at $\mathrm{pH}$ close to 7 [83]. This assists the antimicrobial agents which have positive charges or domains to attract and capture them [21], (2) Destroy the micro-organism membrane or its biomolecules which are essentials for the living of the micro-organism such as proteins, DNA, and RNA [84]. Usually, three strategies have been applied to make antimicrobial filters: (1) Using polymers with inherent antimicrobial properties, (2) Introducing nanoparticles that have an antimicrobial effect on the membrane. This can be achieved by blending the nanoparticles to the polymer before making the filter or coating the polymeric membrane with the nanoparticles [85-87], (3) coating the filter with the bio-antibacterial molecules $[78,88,89]$. 


\subsection{Antimicrobial Polymers}

Some polymers such as Chitosan (CS) and Polymethyl acrylate (PMA) have inherent antibacterial/antiviral properties usually due to their positively charged domain structure which capture and disrupt the membrane of micro-organisms. Among them, CS and some of its derivatives enjoy advantages such as relatively good antimicrobial activity, biodegradability, and non-toxicity which attract a lot of attention recently [77]. Both antibacterial and antifungal have been reported for CS, which makes it suitable for the food, agriculture, and pharmaceutical industry. The CS antibacterial properties may come from the protonated anion groups in their main structure. These protonated anion groups can interact with the phosphoryl groups of the phospholipids via electrostatic forces [90].

Chitosan, however, suffers from poor mechanical strength and low solubility on most of the solvents. To tackle this problem CS is usually blended or coated with other polymers. Some modifications to the polymer structure of the CS have also been developed to improve the solubility and antibacterial properties. For example, quaternized chitosan $(\mathrm{QCh})$ has better antibacterial properties than plain CS [78], or sulfonated CS shows better solubility in the water and exhibits high antibacterial activity against E. coli [90]. It has also been reported that one of the sulfated derivatives of CS (sulfated chitooligosaccharide) can inhibit HIV-1, which may have potential application for medicine to control HIV [91]. Additionally, it was observed that N-[(2-hydroxy-3- trimethylammonium)propyl] chitosan chloride (HTCC) could inhibit some of the coronaviruses by attachment to the Spike protein of the coronaviruses [92]. Even there is a report on the effectiveness of HTCC on inhibition of the new coronavirus or SARS-CoV-2 [93]. It should be mentioned that electrospun modified chitosan was utilized successfully for both water treatment [94-98] and air filtration [99-101].

\subsection{Composting Antimicrobial Nanoparticles}

Compositing nanoparticles (NP) with polymers by electrospinning is another approach for making antibacterial air filters. Nanoparticles of metals (e.g., copper and silver), metal oxides (e.g., $\mathrm{ZnO}, \mathrm{CuO}, \mathrm{TiO}_{2}$ ), metal salts (e.g., $\mathrm{CuSO}_{4}$ ), metal hydroxides (e.g., $\mathrm{Cu}(\mathrm{OH})_{2}$, $\left.\mathrm{Ca}(\mathrm{OH})_{2}, \mathrm{Mg}(\mathrm{OH})_{2}\right)$, polymers (e.g., Poly(4-vinyl pyridine) or P-4VP), and carbon nanotubes (CNTs) have been examined for their antibacterial properties. They sometimes blended with the polymers via in-situ (blending the NP precursor (s) with polymer followed by nucleation) or ex-situ (blending the available NP with the polymers) techniques. Although the in-situ method is usually more complicated for controlling the process, the final product mostly enjoys more uniform particle distribution in the fibers. This can be seen in experiments performed by $\mathrm{Mu}$ et al. and Wang et al. [30,102]. In an ex-situ case, if the polymer solution has a lower viscosity, the NP can come to the polymer surface easier, leading the membrane to exhibit more antibacterial activity [78].

On the other hand, sometimes nanoparticles are coated on the membrane surface to achieve higher antibacterial performance [78]. Physical methods such as dip-coating, layerby-layer (LBL) coating, spray coating, nebulization process, and electrospray [79], as well as chemical methods such as grafting [78], have been utilized to decorate the membrane with antibacterial NP.

\subsubsection{Metallic Nanoparticles}

Both silver and copper nanoparticles and their compounds (metal oxide, metal hydrate, etc.) have been well known for their antibacterial/antiviral properties [79]. The antibacterial effect of silver has been known since 1000 BCE in the healthy additives in Chinese and Indian medicines. However, it was discovered recently that reducing the size of silver to the nano range can improve the antibacterial properties of silver significantly. Research shows that silver can react with the sulfur in some of the protein on the bacteria membrane cell leading to disinfection of the bacteria. The released silver ion from silver nanoparticles can also diffuse into the cell and interact with the phosphorus in the backbone of DNA molecules. Moreover, silver ions can react with phosphor-containing proteins and inhibit 
them (Figure 14). Additionally, it has been reported if the size of silver NP became less than $10 \mathrm{~nm}$, they can make pores on the bacteria cell membrane, which can cause the discharge of the cytoplasm and kill the bacteria without interaction with the cells' proteins and the genetic molecules. It is noteworthy that the size and the shape of silver NP can influence their antibacterial effect. If the size of the nanoparticles is less than $20 \mathrm{~nm}$, the silver NP shows greater attraction to the sulfur-containing proteins which enhance the antibacterial activity dramatically. The truncated triangular shape of silver nanoplates shows higher antibacterial activity in comparison with spherical and rod-shaped NP [84].

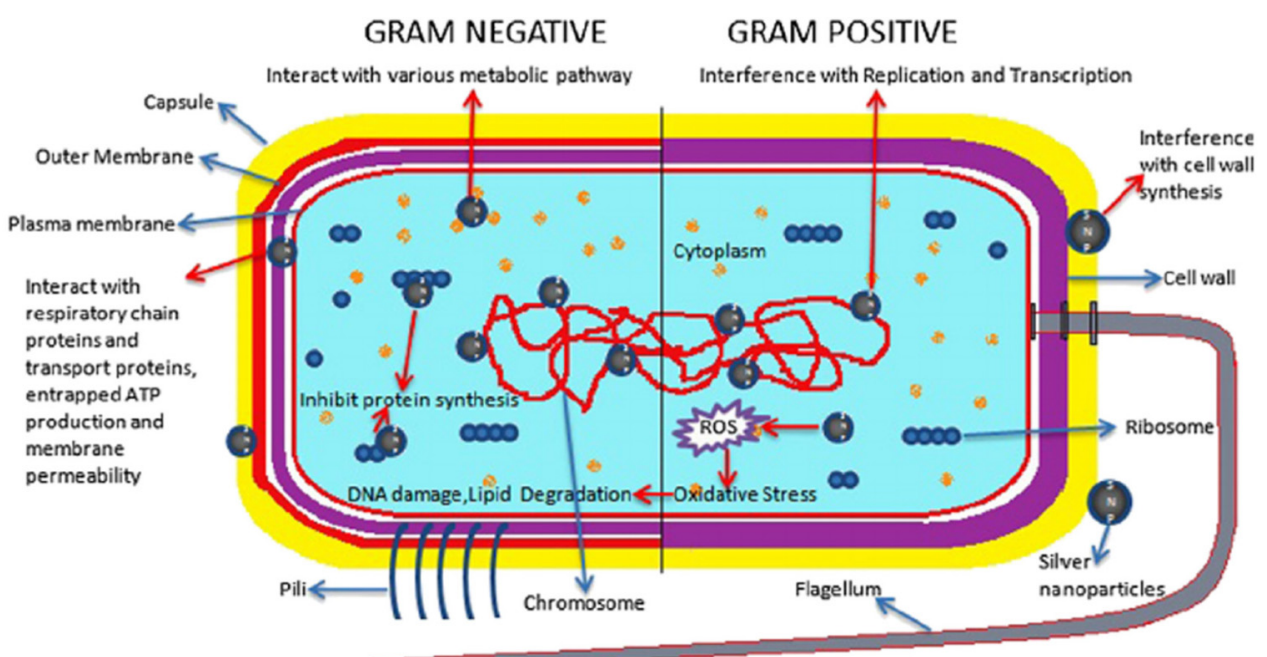

Figure 14. An example of the disinfection mechanism of an antimicrobial agent (silver nanoparticles) on the bacteria (Reprinted with permission from [86]. Copyright 2019 Elsevier).

Although silver nanoparticles are well known for their antibacterial properties, it has been observed that they can also be effective on viral disinfection [103,104]. $11 \mathrm{~nm}$ silver particles were synthesized and used as a coating on an air filter. The coating increased the anti-viral ability of the filter. However, with larger dust loading, the filtration and pressure drop increased as the anti-viral ability decreased. This is likely due to the dust on the silver nanoparticles stopping contact between the virus particles and the silver coating $[59,105,106]$.

Although silver nanoparticles are very effective for the disinfection of bacteria, there are some health and environmental concerns associated with their use. Argyria is a disease that changes the color of the skin to dark bluish and is caused by exposure to silver. The threshold concentration for argyria is usually much higher than the amount of silver used for disinfection, but it raises the concern of toxicity for the antibacterial application. The negative impact of silver NP on aquatic species is another concern of their wider application [84]. A study completed by Gliga et al. has also revealed the possibility of considerable toxicity to human lung cells [107], potentially limiting their application for air filters.

Like silver, copper can disinfect both viruses and bacteria and can be woven into micro/nanofibers [108,109]. Bulk copper has been exhibited excellent antimicrobial activity against a relatively wide range of pathogens such as bacteria, fungi, and viruses [110]. It has also been reported that after exposure to a copper surface to SARS-CoV-2, no active SARS-CoV-2 can be detected after four hours [111]. Copper NP also proves great activity in the disinfection of micro-organisms (no matter their types) [110].

Copper may bond to thiol or other peptide groups of the micro-organism's proteins which disrupt the enzyme structure. It has been reported that copper can deactivate the membrane respiratory enzymes of E. coli [112]. Copper can also attack the cell membrane via lipid peroxidation [113]. Furthermore, copper ions can diffuse into the cell, attack the genetic molecules, and make them lose their functionalities. For example, copper (II) 
can compete with the hydrogen bond of DNA double strands and denature its reversibility [112].

Some research shows excellent improvement against biofilm formation in ventilation and air-conditioning (HVAC) systems if they are made of copper instead of aluminum [113,114].

Although copper is a necessary mineral for regular body function overexposure to copper can come with some severe side effects. Common side effects of copper toxicity are headaches, diarrhea, inflammation, and can result in kidney failure. Copper nano-toxicity is also an issue that is being studied. It is found that the nano-toxicity of copper impacts males more heavily than females. It can cause spleen, liver, kidney, and respiratory damage [115]. The most common way for copper toxicity to occur is through food or water consumption, but trace amounts of copper can also be found in the air.

\subsubsection{Metal Oxide Nanoparticles}

Zinc oxide $(\mathrm{ZnO})$ nanoparticles are one of the most important inorganic antimicrobial agents that have been suggested for the prevention of biofilm formation. Its effectiveness on a wide variety of bacteria and fungi $[116,117]$ and low toxicity of ZnO NP make them attractive to use extensively in the food, textile, and medicine industry $[115,116]$. Although the exact antimicrobial mechanism of $\mathrm{ZnO}$ is not clear yet, it has been suggested that $\mathrm{ZnO}$ generates reactive oxygen species (ROS) such as $\mathrm{H} 2 \mathrm{O} 2$ in the presence of water which can disrupt the cell membrane $[117,118]$. Furthermore, they can damage the bacteria cell membrane leading to leakage of the membrane, causing cell death [117].

$\mathrm{ZnO}$ is being used in the fight against the SARS-CoV-2 virus mainly as a disinfectant spray. It was found that at a very low concentration, IC50 $=526 \mathrm{ng} / \mathrm{mL}$, and it can cause oxidative stress to the SARS-CoV-2 virus which causes severe damage to the virus' cellular membrane, which is necessary for fighting the SARS-CoV-2 virus. [119,120]

Titanium dioxide (TiO2) is one of the effective ceramic materials that exhibit antimicrobial activity. Since the first report of antimicrobial activity of TiO2 in 1985 by Matsunaga et al. [121], it attracts much attention due to its low toxicity as well as high physical and chemical activity [122]. Titanium dioxide has three different allotropes: rutile, anatase, and brookite, but anatase is mostly used for extraordinary photocatalyst activity. Although a variety of micro-organisms can be disinfected by titanium dioxide, it is more effective on viruses and bacteria than fungus.

The mechanism of antimicrobial activity of titanium dioxide is not clear, yet. For the titanium dioxide powder, it is considered that the micro-organisms should attach to the Titanium dioxide particles first, but for the titanium dioxide polymer composite, this part may not be a key step for the disinfection [123]. It is also proposed that exposure to UV light can provide enough electron-hole which promote producing ROS such as hydrogen peroxide [118] as well as oxide (such as superoxide) spices under visible light (which has a mild effect on antimicrobial activity) for the second step [123-125]. Similar to zinc oxide these species can disinfect the micro-organisms by damaging the cell membranes. Furthermore, they can damage DNA and other macro-molecules which cause cell death. The excitement energy, the size, and the surface of the titanium dioxide particles, type of micro-organism. Temperature, etc. are some of the factors that can control the antimicrobial activity of titanium dioxide [124], but it has been reported that the membrane damage can take place in less than $20 \mathrm{~min}$ [118].

The main limitation of using titanium dioxide is its wide bandgap which needs only UV radiation to activate the photocatalytic oxidation leading to low photocatalytic efficiency and high electron-hole recombination rate. To tackle this problem, different dopants such as $\mathrm{Cu}, \mathrm{Ag}, \mathrm{Zn}, \mathrm{Y}$ (or a combination of $\mathrm{Zn}$ and $\mathrm{Y}$ ) have been used to make it effective under visible light or even without the light [122].

Disinfecting air, water, and surfaces with the photocatalytic reaction of $\mathrm{LED}-\mathrm{TiO}_{2}$ have been proven useful against many micro-organisms, including human coronavirus, and SARS coronavirus. It was found that the $\mathrm{TiO}_{2}$ photocatalytic reaction for 20 min inactivated 
99.9\% of SARS-CoV-2 in aerosols and for $120 \mathrm{~min}$ it inactivated $99.9 \%$ of SARS-CoV-2 in liquids [126,127].

\subsubsection{Carbon Nanostructure}

Carbon nanostructures such as carbon nanotubes (single-wall, multi-wall), fullerene, and graphene (pristine graphene, graphene oxide, reduced graphene oxide) have also exhibited antimicrobial activity. The exact mechanism for their antibacterial properties is not fully understood, but ROS production is one of the proposed mechanisms that have been considered for almost all of them, especially for fullerene (Figure 15) [128]. Besides that, other mechanisms have been proposed for each carbon nanostructure. For example, for fullerene, mechanisms such as intervening in the respiratory chain, destroying the cell membrane, and intercalation with the membrane lipid have also been considered. One of the proposed mechanisms for CNT is a perturbation of the cell membrane and releasing its intracellular content [105]. For graphene-based nano carbons, their sharp edge, as well as their high hydrophobicity, can cause membrane distortion leading to the death of the micro-organism [128-130].

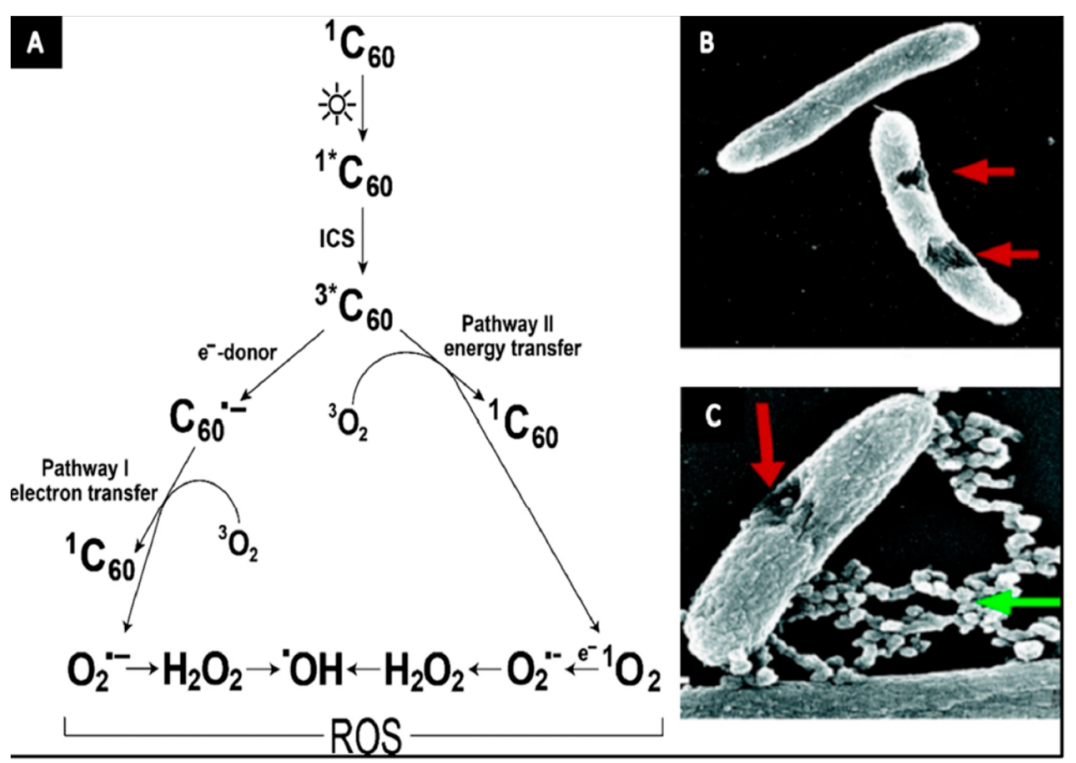

Figure 15. Fullerene $\mathrm{C} 60$ photochemical pathways leading to reactive oxygen species, ROS, generation (A), Damaged S. oneidensis MR-1 cells treated with C60-NH2 (B,C) [128].

Single-walled carbon nanotubes (SWCNT) can be used to detect SARS-CoV-2. The SWCNT is functionalized with ACE2, which is a host protein that has a high binding affinity for the SARS-Cov_2 virus spike protein. [131] Carbon-based nanomaterials (CBN), being antimicrobial, can physically interact with the SARS-CoV-2 virus and through membrane distortion, which also works on the virus even if it is resistant to other treatments [131].

\subsection{Bio-Antimicrobial Molecules}

Recently, natural antimicrobial products have been examined to be introduced into air filters to improve their antimicrobial performance. Having high antimicrobial activity, less toxicity, being more environmentally friendly, and biodegradability are some of their advantages over inorganic additives (such as $\mathrm{Cu}$ and $\mathrm{Ag}$ ) [78,79]. Additives such as Euscaphis japonica, GSE, Propolis, and Sericin have been tested successfully for producing antimicrobial air filters [79]. Antimicrobial peptides (AMPs) and bacteriolytic enzymes are two classes of the natural molecules produced by living cells to protect them against micro-organisms' threads, and they have a lot of potential applications, including the use in antimicrobial air filters [78]. In this paper, antimicrobial peptides (AMPs) are discussed 
as an example. However, other types of bio-antimicrobial molecules also have potential applications in antimicrobial air filters.

Antimicrobial peptides (AMPs) are relatively small biological molecules to serve as the front defense line of the living species [132]. They are categorized as small polypeptides (30-60 aa), with high-temperature stability $\left(100{ }^{\circ} \mathrm{C}, 15 \mathrm{~min}\right)$, no impact on eukaryotic cells [133], and they can work under a wide $\mathrm{pH}$ range. They are effective for disinfecting a wide variety of micro-organisms, including bacteria (Gram-positive, Gram-negative, Grampositive and negative), viruses, fungi, and parasites (such as protozoan). Even some studies have been reported for the anti-cancer activities of AMPs [133]. It should be mentioned that some classes of AMPs, for example, $\beta$-defensins, indolicidin, cecropin A, and magainin, can disinfect bacteria, fungi, viruses, and parasites at the same time. In a word, one AMP can kill a variety of different kinds of micro-organisms [134].

The AMP-mediated killing process can act completely very quickly (even in the range of a few seconds) after connecting to the micro-organism's membrane [135]. The net charge of AMPs is positive, which assists them in attracting and attaching to the micro-organisms' cell membrane that is usually negative [136]. The binding process then usually becomes enhanced by adapting their amphipathic structure to the cell membrane. After this point, the mechanism for disrupting the cell membrane is not clear yet [135]. However, four mechanisms, namely, Toroidal pore, Carpet-like, Barrel-stave, and Aggregate, have been proposed to explain how AMPs can make holes or channels in the cell membrane, which causes to interrupt the cell function and kill the cell (Figure 16) [133]. Describing the four proposed mechanisms is beyond the scope of this article, but there are several valuable resources (e.g., $[133,137])$ that the reader can refer to them to become familiar with these mechanisms. It should also be mentioned that the mechanisms explain how the AMPs interact and disinfect the lipid membrane micro-organisms. For the envelope viruses, AMPs (or rather antiviral peptides) integrate into the viral envelope or the host cells to deactivate the viruses [135].

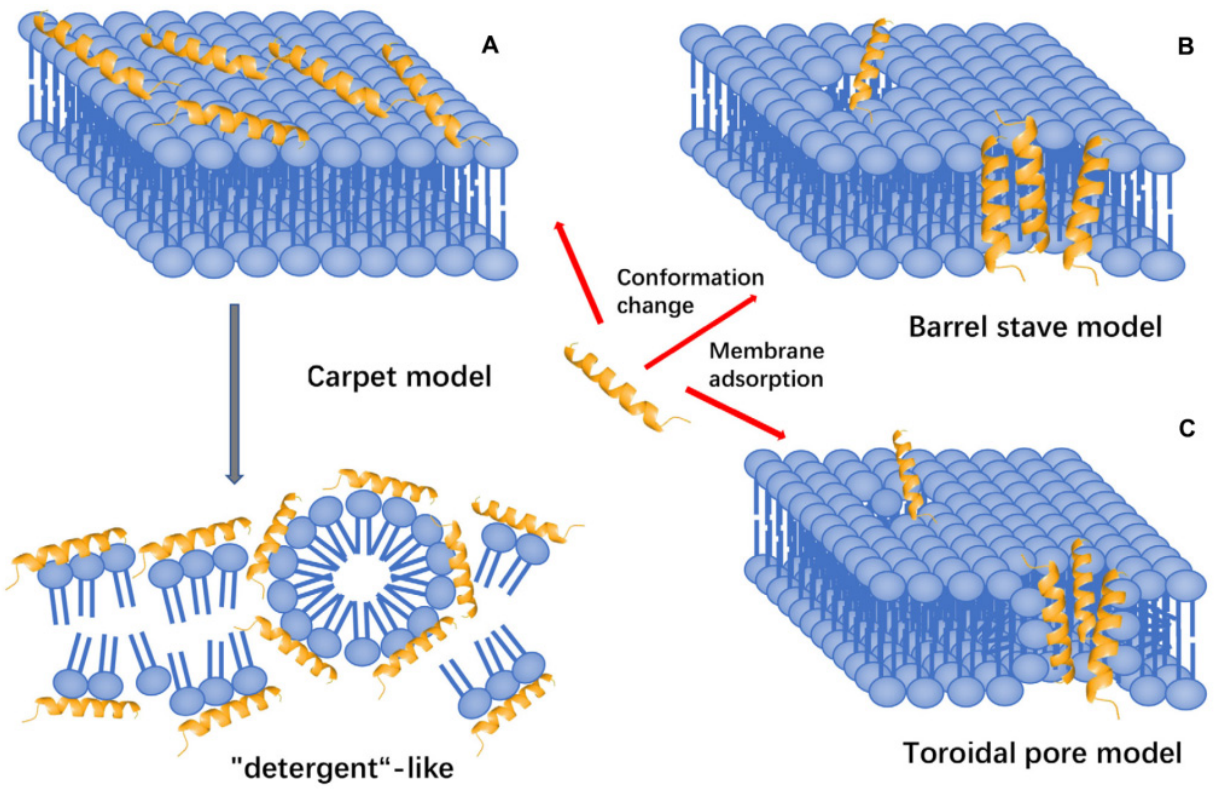

Figure 16. AMP'S mode of action (A) Carpet model: attaching of AMPs on the surface of the membrane and destroying the cell membrane like a "detergent." (B) Barrel stave model: AMPs aggregate with each other, diffuse into the cell membrane, and form a channel. (C) Toroidal pore model: accumulation of AMPs vertically embeds in the cell membrane, which leads to bending to make a ring hole [138].

Although the main applications or potential applications of AMPs are in the pharmaceutical industry (especially for targeting the antibiotic resistance bacteria) and food 
industry (to substitute with chemical food preservatives) [133], some research has been completed on their use as antimicrobial air filters [139].

It is noteworthy that most of the antimicrobial natural product air filters have been tested under controlled experimental conditions, which may reach a different result in practice. Additionally, the durability of these products is questionable because they are vulnerable to degradation owing to the natural oxidation process [79]. If these two problems are addressed, they can be used in the structure of air filters in the future to improve their anti-microbial properties.

Author Contributions: Conceptualization, I.A.B. and R.A.R.; validation, R.A.R.; formal analysis, I.A.B.; investigation, I.A.B. and G.G.; writing—original draft preparation, I.A.B.; writing—review \& editing, G.G.; supervision, R.A.R.; funding acquisition, R.A.R. All authors have read and agreed to the published version of the manuscript.

Funding: Financial support for this research is provided by the Natural Sciences and Engineering Research Council of Canada (NSERC) Alliance COVID-19.

Data Availability Statement: Permission for all figures used was provided by corresponding authors for their original papers.

Conflicts of Interest: The authors declare that they have no conflict of interest.

\section{References}

1. Fortune Business Insights. Available online: https://www.fortunebusinessinsights.com/industry-reports/air-filters-market-10 1676 (accessed on 19 August 2021).

2. Coccia, M. How do low wind speeds and high levels of air pollution support the spread of COVID-19. Atmos. Pollut. Res. 2021, 2, 437-445. [CrossRef]

3. Bahri, M.; Haghighat, F.; Rohani, S.; Kazemian, H. Impact of design parameters on the performance of non-thermal plasma air purification system. Chem. Eng. J. 2016, 302, 204-212. [CrossRef]

4. Schweinheim, C. Setting standards for HEPA filter efficiency. Filtr. Sep. 2015, 52, 13-15. [CrossRef]

5. News Medical. Available online: https://www.news-medical.net/health/The-Size-of-SARS-CoV-2-Compared-to-Other-Things. aspx\#: \{\}:text=To\%20date\%2C\%20research\%20has\%20\%20shown,as\%20large \%20as\%\%2020500\%20nm (accessed on 25 August 2021).

6. Kothari, V.K.; Das, A.; Singh, S. Filtration behaviour of woven and nonwoven fabrics. Indian, J. Fibre Text Res. 2007, 32, $214-220$.

7. Yeom, B.Y.; Pourdeyhimi, B. Aerosol filtration properties of PA6/PE islands-in-the-sea bicomponent spunbond web fibrillated by high-pressure water jets. J. Mater. Sci. 2011, 46, 5761-5767. [CrossRef]

8. Geus, H.G. Developments in manufacturing techniques for technical nonwovens. Adv. Tech. Nonwovens 2016, 133-153. [CrossRef]

9. Hassan, M.A.; Yeom, B.Y.; Wilkie, A.; Pourdeyhimi, B.; Khan, S.A. Fabrication of nanofiber meltblown membranes and their filtration properties. J. Membr. Sci. 2013, 427, 336-344. [CrossRef]

10. Demir, M.M.; Yilgor, I.; Yilgor, E.; Erman, B. Electrospinning of polyurethane fibers. Polymers 2002, 43, 3303-3309. [CrossRef]

11. Buivydiene, D.; Krugly, E.; Ciuzas, D.; Tichonovas, M.; Kliucininkas, L.; Martuzevicius, D. Formation and characterisation of air filter material printed by melt electrospinning. J. Aerosol. Sci. 2019, 131, 48-63. [CrossRef]

12. China-Supplie. Available online: http://www.china-supplie.com/difference-between-spunbond-and-meltblown/ (accessed on 13 July 2021).

13. Hao, X.; Zeng, Y. A review on the studies of air flow field and fiber formation process during melt blowing. Ind. Eng. Chem. Res. 2019, 58, 11624-11637. [CrossRef]

14. Nonwovens Industry. Available online: https://www.nonwovens-industry.com/contents/view_features/2005-08-17 / spunbonded--melt-blown-nonwovens / (accessed on 14 July 2021).

15. Saleem, H.; Trabzon, L.; Kilic, A.; Zaidi, S.J. Recent advances in nanofibrous membranes: Production and applications in water treatment and desalination. Desalination 2020, 478, 114178. [CrossRef]

16. Henry, J.J.; Goldbach, J.; Stabler, S.; Devisme, S.; Chauveau, J. Advancements in the production of meltblown fibres. Filtr. Sep. 2016, 53, 36-40. [CrossRef]

17. Wu, W.; Sota, H.; Hirogaki, T.; Aoyama, E. Investigation of air filter properties of nanofiber nonwoven fabric manufactured by a modified melt-blowing method along with flash spinning method. Precis. Eng. 2021, 68, 187-196. [CrossRef]

18. Sim, K.M.; Park, H.S.; Bae, G.N.; Jung, J.H. Antimicrobial nanoparticle-coated electrostatic air filter with high filtration efficiency and low pressure drop. Sci. Total Environ. 2015, 533, 266-274. [CrossRef]

19. Liu, F.; Li, M.; Shao, W.; Yue, W.; Hu, B.; Weng, K.; Chen, Y.; Liao, X.; He, J. Preparation of a polyurethane electret nanofiber membrane and its air-filtration performance. J. Colloid Interface Sci. 2019, 557, 318-327. [CrossRef]

20. Kilic, A.; Russell, S.; Shim, E.; Pourdeyhimi, B. The charging and stability of electret filters. In Fibrous Filter Media; Woodhead Publishing: Sawston, UK, 2017; pp. 95-121. 
21. Zhu, M.; Han, J.; Wang, F.; Shao, W.; Xiong, R.; Zhang, Q.; Pan, H.; Yang, Y.; Samal, S.K.; Zhang, F.; et al. Electrospun nanofibers membranes for effective air filtration. Macromol. Mater. Eng. 2017, 302, 1600353. [CrossRef]

22. Xue, J.; Wu, T.; Dai, Y.; Xia, Y. Electrospinning and electrospun nanofibers: Methods, materials, and applications. Chem. Rev. 2019, 119, 5298-5415. [CrossRef]

23. Haider, A.; Haider, S.; Kang, I.K. A comprehensive review summarizing the effect of electrospinning parameters and potential applications of nanofibers in biomedical and biotechnology. Arab. J. Chem. 2018, 11, 1165-1188. [CrossRef]

24. Bhardwaj, N.; Kundu, S.C. Electrospinning: A fascinating fiber fabrication technique. Biotech. Adv. 2010, 28, 325-347. [CrossRef]

25. Reneker, D.H.; Yarin, A.L. Electrospinning jets and polymer nanofibers. Polymers 2008, 49, 2387-2425. [CrossRef]

26. Zhang, S.; Rind, N.A.; Tang, N.; Liu, H.; Yin, X.; Yu, J.; Ding, B. Electrospun Nanofibers for Air Filtration. In Electrospinning: Nanofabrication and Applications; William Andrew Publishing: Norwich, NY, USA, 2019; pp. 365-389.

27. Gao, H.; He, W.; Zhao, Y.B.; Opris, D.M.; Xu, G.; Wang, J. Electret mechanisms and kinetics of electrospun nanofiber membranes and lifetime in filtration applications in comparison with corona-charged membranes. J. Memb. Sci. 2020, 600, 117879. [CrossRef]

28. Collins, G.; Federici, J.; Imura, Y.; Catalani, L.H. Charge generation, charge transport, and residual charge in the electrospinning of polymers: A review of issues and complications. J. Appl. Phys. 2012, 111, 44701. [CrossRef]

29. Niu, Z.; Bian, Y.; Xia, T.; Zhang, L.; Chen, C. An optimization approach for fabricating electrospun nanofiber air filters with minimized pressure drop for indoor PM2.5 control. Build. Environ. 2021, 188, 107449. [CrossRef]

30. Bian, Y.; Zhang, L.; Chen, C. Experimental and modeling study of pressure drop across electrospun nanofiber air filters. Build. Environ. 2018, 142, 244-251. [CrossRef]

31. Xia, T.; Chen, C. Evolution of pressure drop across electrospun nanofiber filters clogged by solid particles and its influence on indoor particulate air pollution control. J. Hazard. Mater. 2021, 402, 123479. [CrossRef] [PubMed]

32. Cui, J.; Wang, Y.; Lu, T.; Liu, K.; Huang, C. High performance, environmentally friendly and sustainable nanofiber membrane filter for removal of particulate matter. J. Colloid Interface Sci. 2021, 597, 48-55. [CrossRef]

33. Rashid, T.U.; Gorga, R.E.; Krause, W.E. Mechanical Properties of Electrospun Fibers-A Critical Review. Adv. Eng. Mater. 2019, 23, 153. [CrossRef]

34. Nauman, S.; Lubineau, G.; Alharbi, H.F. Post Processing Strategies for the Enhancement of Mechanical Properties of ENMs (Electrospun Nanofibrous Membranes): A Review. Membranes 2021, 11, 39. [CrossRef]

35. Li, B.; Liu, Y.; Wei, S.; Huang, Y.; Yang, S.; Xue, Y.; Xuan, H.; Yuan, H. A Solvent System Involved Fabricating Electrospun Polyurethane Nanofibers for Biomedical Applications. Polymers 2020, 12, 3038. [CrossRef]

36. D'Amato, A.; Schaub, N.J.; Cardenas, J.M.; Franz, E.; Rende, D.; Ziemba, A.; Gilbert, R. Evaluation of procedures to quantify solvent retention in electrospun fibers and facilitate solvent removal. Fib. Polym. 2017, 18, 483-492. [CrossRef]

37. Nayak, R.; Padhye, R.; Arnold, L. Melt-electrospinning of nanofibers. In Electrospun Nanofibers; Woodhead Publishing: Sawston, UK, 2017; pp. 11-40.

38. Zhang, L.H.; Duan, X.P.; Yan, X.; Yu, M.; Ning, X.; Zhao, Y.; Long, Y.Z. Recent advances in melt electrospinning. RSC Adv. 2016, 6, 53400-53414. [CrossRef]

39. De-Ling, L. Developments in Surface Contamination and Cleaning. In Particle Deposition onto Enclosure Surfaces; Kohli, R., Mittal, K.L., Eds.; William Andrew Publishing: Norwich, NY, USA, 2010; Chapter 1; pp. 1-56.

40. Akbar-Khanzadeh, F.; Smigielski, K. Design and Set up of an Air Filter Testing Unit to Demonstrate Characteristics and Performance of Particulate Air Filters. Int. J. Occup. Hyg. 2006, 1, 1-8.

41. Robert, B.; Nallathambi, G. A concise review on electrospun nanofibres/nanonets for filtration of gaseous and solid constituents (PM2. 5) from polluted air. Coll. Intface Sci. Comm. 2020, 37, 100275.

42. Gardner, P.D.; Eshbaugh, J.P.; Harpest, S.D.; Richardson, A.W.; Hofacre, K.C. Viable viral efficiency of N95 and P100 respirator filters at constant and cyclic flow. J. Occup. Environ. Hyg. 2013, 10, 564-572. [CrossRef] [PubMed]

43. Bian, Y.; Wang, S.; Zhang, L.; Chen, C. Influence of fiber diameter, filter thickness, and packing density on PM2.5 removal efficiency of electrospun nanofiber air filters for indoor applications. Build. Environ. 2020, 170, 106628. [CrossRef]

44. Leung, W.W.; Hung, C.H.; Yuen, P.T. Effect of face velocity, nanofiber packing density and thickness on filtration performance of filters with nanofibers coated on a substrate. Sep. Pur. Tech. 2010, 71, 30-37. [CrossRef]

45. Dharmanolla, S.; Chase, G.G. Computer program for filter media design optimization. J. Chin. Inst. Chem. Eng. 2008, 39, 161-167. [CrossRef]

46. Seok, J.; Chun, K.M.; Song, S.; Lee, S. Study on the filtration behavior of a metal fiber filter as a function of filter pore size and fiber diameter. J. Aerosol. Sci. 2015, 81, 47-61. [CrossRef]

47. Gustafsson, S.; Mihranyan, A. Strategies for Tailoring the Pore-Size Distribution of Virus Retention Filter Papers. ACS Appl. Mater. Interfaces 2016, 8, 13759-13767. [CrossRef] [PubMed]

48. Griffiths, I.M.; Mitevski, I.; Vujkovac, I.; Illingworth, M.R.; Stewart, P.S. The role of tortuosity in filtration efficiency: A general network model for filtration. J. Memb. Sci. 2020, 598, 117664. [CrossRef]

49. Wang, N.; Si, Y.; Wang, N.; Sun, G.; El-Newehy, M.; Al-Deyab, S.S.; Ding, B. Multilevel structured polyacrylonitrile/silica nanofibrous membranes for high-performance air filtration. Sep. Purif. Tech. 2014, 126, 44-51. [CrossRef]

50. Wang, Z.; Zhao, C.; Pan, Z. Porous bead-on-string poly (lactic acid) fibrous membranes for air filtration. J. Coll. Intrfc. Sci. 2015, 441, 121-129. [CrossRef] [PubMed] 
51. Huang, J.J.; Tian, Y.; Wang, R.; Tian, M.; Liao, Y. Fabrication of bead-on-string polyacrylonitrile nanofibrous air filters with superior filtration efficiency and ultralow pressure drop. Sep. Purif. Tech. 2020, 237, 116377. [CrossRef]

52. Rajak, A.; Hapidin, D.A.; Iskandar, F.; Munir, M.M.; Khairurrijal, K. Electrospun nanofiber from various source of expanded polystyrene (EPS) waste and their characterization as potential air filter media. WST Manag. 2020, 103, 76-86. [CrossRef] [PubMed]

53. Yun, K.M.; Suryamas, A.B.; Iskandar, F.; Bao, L.; Niinuma, H.; Okuyama, K. Morphology optimization of polymer nanofiber for applications in aerosol particle filtration. Sep. Purif. Tech. 2010, 75, 340-345. [CrossRef]

54. Jiang, P.; Zhao, X.; Li, Y.; Liao, Y.; Hua, T.; Yin, X.; Yu, J.; Ding, B. Moisture and oily molecules stable nanofibrous electret membranes for effectively capturing PM2. 5. Comp. Comm. 2017, 6, 34-40. [CrossRef]

55. Leung, W.W.F.; Sun, Q. Electrostatic charged nanofiber filter for filtering airborne novel coronavirus (COVID-19) and nanoaerosols. Sep. Purif. Technol. 2020, 250, 116886. [CrossRef] [PubMed]

56. Liu, C.; Hsu, P.C.; Lee, H.W.; Ye, M.; Zheng, G.; Liu, N.; Li, W.; Cui, Y. Transparent air filter for high-efficiency PM 2.5 capture Nat. Comm. 2015, 6, 1-9.

57. Liu, L.; Lv, F.; Li, P.; Ding, L.; Tong, W.; Chu, P.K.; Zhang, Y. Preparation of ultra-low dielectric constant silica/polyimide nanofiber membranes by electrospinning. Comp. Part. A Appl. Sci. Manfctr. 2016, 84, 292-298. [CrossRef]

58. Li, X.; Wang, N.; Fan, G.; Yu, J.; Gao, J.; Sun, G.; Ding, B. Electret polyetherimide-silica fibrous membranes for enhanced filtration of fine particles. J. Coll. Intrfc. Sci. 2015, 439, 12-20. [CrossRef]

59. Wang, S.; Zhao, X.; Yin, X.; Yu, J.; Ding, B. Electret polyvinylidene fluoride nanofibers hybridized by polytetrafluoroethylene nanoparticles for high-efficiency air filtration. ACS Appl. Mater Intrfcs. 2016, 8, 23985-23994. [CrossRef]

60. Maddah, H.A. Polypropylene as a promising plastic: A review. Am. J. Polym. Sci. 2016, 6, 1-11.

61. Liu, H.; Huang, J.; Mao, J.; Chen, Z.; Chen, G.; Lai, Y. Transparent Antibacterial Nanofiber Air Filters with Highly Efficient Moisture Resistance for Sustainable Particulate Matter Capture. iScience 2019, 19, 214-223. [CrossRef] [PubMed]

62. Srisitthiratkul, C.; Pongsorrarith, V.; Intasanta, N. The potential use of nanosilver-decorated titanium dioxide nanofibers for toxin decomposition with antimicrobial and self-cleaning properties. Appl. Surf. Sci. 2011, 257, 8850-8856. [CrossRef]

63. de Man, P.; van Straten, B.; van den Dobbelsteen, J.; van der Eijk, A.; Horeman, T.; Koeleman, H. Sterilization of disposable face masks by means of standardized dry and steam sterilization processes; an alternative in the fight against mask shortages due to COVID-19. J. Hosp. Infect. 2020, 105, 356-357. [CrossRef]

64. Leung, W.W.; Sun, Q. Charged PVDF multilayer nanofiber filter in filtering simulated airborne novel coronavirus (COVID-19) using ambient nano-aerosols. Sep. Purif. Technol. 2020, 245, 116887. [CrossRef]

65. Buivydiene, D.; Todea, A.M.; Asbach, C.; Krugly, E.; Martuzevicius, D.; Kliucininkas, L. Composite micro/nano fibrous air filter by simultaneous melt and solution electrospinning. J. Aerosol Sci. 2021, 154, 105754. [CrossRef]

66. Wang, X.; Xiang, H.; Song, C.; Zhu, D.; Sui, J.; Liu, Q.; Long, Y. Highly efficient transparent air filter prepared by collectingelectrode-free bipolar electrospinning apparatus. J. Hazard. Mater. 2020, 385, 121535. [CrossRef]

67. Liu, J.; Dunne, F.O.; Fan, X.; Fu, X.; Zhong, W.H. A protein-functionalized microfiber/protein nanofiber Bi-layered air filter with synergistically enhanced filtration performance by a viable method. Sep. Purif. Technol. 2019, 229, 115837. [CrossRef]

68. Zhao, X.; Li, Y.; Hua, T.; Jiang, P.; Yin, X.; Yu, J.; Ding, B. Cleanable air filter transferring moisture and effectively capturing PM2. 5. Small 2017, 13, 1603306. [CrossRef] [PubMed]

69. Park, S.; Koo, H.Y.; Yu, C.; Choi, W.S. A novel approach to designing air filters: Ubiquitous material-based Janus air filter modules with hydrophilic and hydrophobic parts. Chem. Eng. J. 2021, 410, 128302. [CrossRef]

70. Wang, X.; Ding, B.; Sun, G.; Wang, M.; Yu, J. Electro-spinning/netting: A strategy for the fabrication of three-dimensional polymer nano-fiber/nets. Prog. Mater. Sci. 2013, 58, 1173-1243. [CrossRef] [PubMed]

71. Zargham, S.; Bazgir, S.; Tavakoli, A.; Rashidi, A.S.; Damerchely, R. The effect of flow rate on morphology and deposition area of electrospun nylon 6 nanofiber. J. Eng. Fib. Fabr. 2012, 7, 42-49. [CrossRef]

72. Barakat, N.A.; Kanjwal, M.A.; Sheikh, F.A.; Kim, H.Y. Spider-net within the N6, PVA and PU electrospun nanofiber mats using salt addition: Novel strategy in the electrospinning process. Polymers 2009, 50, 4389-4396. [CrossRef]

73. Pant, H.R.; Bajgai, M.P.; Nam, K.T.; Chu, K.H.; Park, S.J.; Kim, H.Y. Formation of electrospun nylon-6/methoxy poly (ethylene glycol) oligomer spider-wave nanofibers. Mater. Lett. 2010, 64, 2087-2090. [CrossRef]

74. Liu, H.; Liu, L.; Yu, J.; Yin, X.; Ding, B. High-efficiency and super-breathable air filters based on biomimetic ultrathin nanofiber networks. Compos. Commun. 2020, 22, 100493. [CrossRef]

75. Ma, H.; Yoon, K.; Rong, L.; Mao, Y.; Mo, Z.; Fang, D.; Hollander, Z.; Gaiteri, J.; Hsiao, B.S.; Chu, B. High-flux thin-film nanofibrous composite ultrafiltration membranes containing cellulose barrier layer. J. Mater. Chem. 2010, 20, 4692-4704. [CrossRef]

76. Yoon, K.; Kim, K.; Wang, X.; Fang, D.; Hsiao, B.S.; Chu, B. High flux ultrafiltration membranes on electrospun nanofibrous PAN scaffolds and chitosan coating. Polymers 2006, 47, 2434-2441. [CrossRef]

77. Gopal, R.; Kaur, S.; Ma, Z.; Chan, C.; Ramakrishna, S.; Matsuura, T. Electrospun nanofibrous filtration membrane. J. Memb. Sci. 2006, 281, 581-586. [CrossRef]

78. Aryanti, P.T.; Sianipar, M.; Zunita, M.; Wenten, I.G. Modified membrane with antibacterial properties. Memb. Water Treat. 2017, 8, 463-481. 
79. Komaladewi, A.A.; Khoiruddin, K.; Surata, I.W.; Subagia, I.D.; Wenten, I.G. Recent advances in antimicrobial air filter. In Proceedings of the 3rd International Tropical Renewable Energy Conference "Sustainable Development of Tropical Renewable Energy" (i-TREC 2018), Kuta, Indonesia, 6-8 September 2018; p. 67.

80. Lee, K.M.; Lee, B.H.; Park, C.J. A study on the Control of Bio-aerosol for Prevention of indoor aerial infection using Antimicrobial air filter. Appl. Mech. Mater. 2013, 284, 1601-1605. [CrossRef]

81. Balagna, C.; Perero, S.; Bosco, F.; Mollea, C.; Irfan, M.; Ferraris, M. Antipathogen nanostructured coating for air filters. Appl. Surf. Sci. 2020, 508, 145283. [CrossRef]

82. Passos da Silva, D.; Schofield, M.C.; Parsek, M.R.; Tseng, B.S. An update on the sociomicrobiology of quorum sensing in gram-negative biofilm development. Pathogens 2017, 6, 51. [CrossRef]

83. Thurman, R.B.; Gerba, C.P.; Bitton, G. The molecular mechanisms of copper and silver ion disinfection of bacteria and viruses. Crit. Rev. Environ. Sci. Tech. 1989, 18, 295-315. [CrossRef]

84. Deshmukh, S.P.; Patil, S.M.; Mullani, S.B.; Delekar, S.D. Silver nanoparticles as an effective disinfectant: A review. Mater. Sci. Eng. 2019, 97, 954-965. [CrossRef]

85. Joe, Y.H.; Woo, K.; Hwang, J. Fabrication of an anti-viral air filter with SiO2-Ag nanoparticles and performance evaluation in a continuous airflow condition. J. Hazard. Mater. 2014, 280, 356-363. [CrossRef] [PubMed]

86. Pan, W.; Wang, J.P.; Sun, X.B.; Wang, X.X.; Jiang, J.; Zhang, Z.G.; Li, P.; Qu, C.H.; Long, Y.Z.; Yu, G.F. Ultra uniform metal-organic framework-5 loading along electrospun chitosan/polyethylene oxide membrane fibers for efficient PM2.5 removal. J. Clean. Prod. 2021, 291, 125270. [CrossRef]

87. Park, K.; Kang, S.; Park, J.; Hwang, J. Fabrication of silver nanowire coated fibrous air filter medium via a two-step process of electrospinning and electrospray for anti-bioaerosol treatment. J. Hazard. Mater. 2021, 411, 125043. [CrossRef]

88. Balagna, C.; Francese, R.; Perero, S.; Lembo, D.; Ferraris, M. Nanostructured composite coating endowed with antiviral activity against human respiratory viruses deposited on fibre-based air filters. Surf. Coat. Technol. 2021, 409, 126873. [CrossRef] [PubMed]

89. Sun, Z.; Yue, Y.; He, W.; Jiang, F.; Lin, C.H.; Pui, D.Y.H.; Liang, Y.; Wanf, J. The antibacterial performance of positively charged and chitosan dipped air filter media. Build. Environ. 2020, 180, 107020. [CrossRef]

90. Dimassi, S.; Tabary, N.; Chai, F.; Blanchemain, N.; Martel, B. Sulfonated and sulfated chitosan derivatives for biomedical applications: A review. Carb. Polym. 2018, 202, 382-396. [CrossRef] [PubMed]

91. Artan, M.; Karadeniz, F.; Karagozlu, M.Z.; Kim, M.M.; Kim, S.K. Anti-HIV-1 activity of low molecular weight sulfated chitooligosaccharides. Carb. Res. 2010, 345, 656-662. [CrossRef] [PubMed]

92. Milewska, A.; Kaminski, K.; Ciejka, J.; Kosowicz, K.; Zeglen, S.; Wojarski, J.; Nowakowska, M.; Szczubiałka, K.; Pyrc, K. HTCC: Broad range inhibitor of coronavirus entry. PLoS ONE. 2016, 11, e0156552. [CrossRef] [PubMed]

93. Milewska, A.; Chi, Y.; Szczepanski, A.; Barreto-Duran, E.; Dabrowska, A.; Botwina, P.; Obloza, M.; Liu, K.; Liu, D.; Guo, X.; et al HTCC as a Polymeric Inhibitor of SARS-CoV-2 and MERS-CoV. J. Virol. 2021, 95, 1-15. [CrossRef] [PubMed]

94. Alipour, S.M.; Nouri, M.; Mokhtari, J.; Bahrami, S.H. Electrospinning of poly(vinyl alcohol)-water-soluble quaternized chitosan derivative blend. Carb. Res. 2009, 344, 2496-2501. [CrossRef]

95. Mi, X.; Vijayaragavan, K.S.; Heldt, C.L. Virus adsorption of water-stable quaternized chitosan nanofibers. Carb. Res. 2014, 387, 24-29. [CrossRef]

96. Mi, X. Electrospun Quaternized Chitosan Fibers for Virus Removal from Drinking Water. Ph.D. Thesis, Michigan Technological University, Houghton, MI, USA, 2013.

97. Sakib, M.N.; Mallik, A.K.; Rahman, M.M. Update on chitosan-based electrospun nanofibers for wastewater treatment: A review. Carb. Polym Technol Appl. 2021, 2, 100064. [CrossRef]

98. Cooper, A.; Oldinski, R.; Ma, H.; Bryers, J.D.; Zhang, M. Chitosan-based nanofibrous membranes for antibacterial filter applications. Carb. Polym. 2013, 92, 254-259. [CrossRef]

99. Lekshmi Mohan, V.; Shiva Nagendra, S.M.; Maiya, M.P. Photocatalytic degradation of gaseous toluene using self-assembled air filter based on chitosan/activated carbon/ $\mathrm{TiO}_{2}$. J. Environ. Chem. Eng. 2019, 7, 103455. [CrossRef]

100. Nie, J.; Xie, H.; Zhang, M.; Liang, J.; Nie, S.; Han, W. Effective and facile fabrication of MOFs/cellulose composite paper for air hazards removal by virtue of in situ synthesis of MOFs/chitosan hydrogel. Carb. Polym. 2020, 250, 116955. [CrossRef]

101. Shao, W.C.; Wu, H.; Shiue, A.; Tseng, C.H.; Wang, Y.W.; Hsu, C.F.; Leggett, G. Chitosan-dosed adsorptive filter media for removal of formaldehyde from indoor air-Performance and cancer risk assessment. Chem. Phys. Lett. 2021, 779, 138836. [CrossRef]

102. Wang, J.; Yang, G.; Wang, L.; Wang, S.; Yan, W.; Ding, S. In-situ fabrication of transition-metal-doped TiO 2 nanofiber/nanosheet structure for high-performance Li storage. J. Alloys Compd. 2019, 787, 1110-1119. [CrossRef]

103. Park, D.H.; Joe, Y.H.; Piri, A.; An, S.; Hwang, J. Determination of Air Filter Anti-Viral Efficiency against an Airborne Infectious Virus. J. Hzrd Mater. 2020, 396, 122640. [CrossRef] [PubMed]

104. Ju, Y.; Han, T.; Yin, J.; Li, Q.; Chen, Z.; Wei, Z.; Zhang, Y.; Dong, L. Bumpy structured nanofibrous membrane as a highly efficient air filter with antibacterial and antiviral property. Sci. Total Environ. 2021, 777, 145768. [CrossRef]

105. Xiao, Y.; Wang, Y.; Zhu, W.; Yao, J.; Sun, C.; Militky, J.; Venkataraman, M.; Zhu, G. Development of tree-like nanofibrous air filter with durable antibacterial property. Sep. Purif. Technol. 2021, 259, 118135. [CrossRef]

106. Sharma, A.; Kumar, S.R.; Katiyar, V.K.; Gopinath, P. Graphene oxide/silver nanoparticle (GO/AgNP) impregnated polyacrylonitrile nanofibers for potential application in air filtration. Nano Struct. Nano Obj. 2021, 26, 100708. [CrossRef] 
107. Gliga, A.R.; Skoglund, S.; Wallinder, I.O.; Fadeel, B.; Karlsson, H.L. Size-dependent cytotoxicity of silver nanoparticles in human lung cells: The role of cellular uptake, agglomeration and Ag release. Part. Fibre Toxicol. 2014, 11, 1-7. [CrossRef]

108. Kim, M.W.; Kim, Y.I.; Park, C.; Aldalbahi, A.; Alanazi, H.S.; An, S.; Yarnim, A.L.; Yoon, S.S. Reusable and durable electrostatic air filter based on hybrid metallized microfibers decorated with metal-organic-framework nanocrystals. J. Mater. Sci. Technol. 2021, 85, 44-55. [CrossRef]

109. Mihut, D.M.; Afshar, A. Electrically assisted silver and copper coated filter papers with enhanced bactericidal effects. Colloids Surf. A Physicochem. Eng. Asp. 2020, 606, 125428. [CrossRef]

110. Longano, D.; Ditaranto, N.; Sabbatini, L.; Torsi, L.; Cioffi, N. Synthesis and antimicrobial activity of copper nanomaterials. In Nano-Antimicrobials; Springer: Berlin/Heidelberg, Germany, 2012; pp. 85-117.

111. Van Doremalen, N.; Bushmaker, T.; Morris, D.H.; Holbrook, M.G.; Gamble, A.; Williamson, B.N.; Tamin, A.; Harcourt, J.L.; Thornburg, N.J.; Gerber, S.I.; et al. Aerosol and surface stability of SARS-CoV-2 as compared with SARS-CoV-1. N. Eng. J. Med. 2020, 382, 1564-1567. [CrossRef]

112. Wang, X.; Ding, B.; Yu, J.; Yang, J. Large-scale fabrication of two-dimensional spider-web-like gelatin nanonets via electro-netting. Colloid Surf. Biointerfaces 2011, 86, 345-352. [CrossRef]

113. Hashmi, M.; Ullah, S.; Kim, I.S. Copper oxide (CuO) loaded polyacrylonitrile (PAN) nanofiber membranes for antimicrobial breath mask applications. Curr. Res. Biotechnol. 2019, 1, 1-10. [CrossRef]

114. Vincent, M.; Hartemann, P.; Engels-Deutsch, M. Antimicrobial applications of copper. Int. J. Hyg. Environ. Health 2016, 219, 585-591. [CrossRef]

115. Hejazy, M.; Koohi, M.K.; Pour, A.B.M.; Najafi, D. Toxicity of manufactured copper nanoparticles-A review. Nanomed. Res. J. 2018, 3, 1-9.

116. Pokhum, C.; Intasanta, V.; Yaipimai, W.; Subjalearndee, N.; Srisitthiratjul, C.; Pongsorrarith, V.; Phanomkate, N.; Chawengkijwanich, C. A facile and cost-effective method for removal of indoor airborne psychrotrophic bacterial and fungal flora based on silver and zinc oxide nanoparticles decorated on fibrous air filter. Atmos. Pollut. Res. 2018, 9, 172-177. [CrossRef]

117. Cao, Y.; Naseri, M.; He, Y.; Xu, C.; Walsh, L.J.; Ziora, Z.M. Non-antibiotic antimicrobial agents to combat biofilm-forming bacteria. J. Glob. Antimic Resist. 2020, 21, 445-451. [CrossRef]

118. Liu, C.; Guo, J.; Yan, X.; Tang, Y.; Mazumder, A.; Wu, S.; Liang, Y. Antimicrobial nanomaterials against biofilms: An alternative strategy. Environ. Rev. 2017, 25, 225-244. [CrossRef]

119. El-Megharbel, S.M.; Alsawat, M.; Al-Salmi, F.A.; Hamza, R.Z. Utilizing of (Zinc Oxide Nano-Spray) for Disinfection against "SARS-CoV-2" and Testing Its Biological Effectiveness on Some Biochemical Parameters during (COVID-19 Pandemic) - "ZnO Nanoparticles Have Antiviral Activity against (SARS-CoV-2)". Coatings 2021, 11, 388. [CrossRef]

120. Ji, S.M.; Tiwari, A.P.; Oh, H.J.; Kim, H.Y. ZnO/Ag nanoparticles incorporated multifunctional parallel side by side nanofibers for air filtration with enhanced removing organic contaminants and antibacterial properties. Colloid Surf. A Physicochem. Eng. Asp. 2021, 621, 126564. [CrossRef]

121. Matsunaga, T.; Tomoda, R.; Nakajima, T.; Wake, H. Photoelectrochemical sterilization of microbial cells by semiconductor powders. FEMS Microbiol. Lett. 1985, 29, 211-214. [CrossRef]

122. Yadav, S.; Jaiswar, G. Review on undoped/doped $\mathrm{TiO} 2$ nanomaterial; synthesis and photocatalytic and antimicrobial activity. J. Chin. Chem. Soc. 2017, 64, 103-116. [CrossRef]

123. Kubacka, A.; Fernández-García, M.; Cerrada, M.L.; Fernández-García, M. Titanium dioxide-polymer nanocomposites with advanced properties. In Nano-Antimicrobials; Springer: Berlin/Heidelberg, Germany, 2012; pp. 119-149.

124. Zheng, X.; Shen, Z.P.; Cheng, C.; Shi, L.; Cheng, R.; Yuan, D.H. Photocatalytic disinfection performance in virus and virus/bacteria system by $\mathrm{Cu}-\mathrm{TiO}_{2}$ nanofibers under visible light. Environ. Pollut. 2018, 237, 452-459. [CrossRef]

125. Bono, N.; Ponti, F.; Punta, C.; Candiani, G. Effect of UV irradiation and TiO2-photocatalysis on airborne bacteria and viruses: An overview. Materials 2021, 14, 1075. [CrossRef]

126. Matsuura, R.; Lo, C.W.; Wada, S.; Somei, J.; Ochiai, H.; Murakami, T.; Saito, N.; Ogawa, T.; Shinjo, A.; Benno, Y.; et al. Sars-cov-2 disinfection of air and surface contamination by $\mathrm{TiO}_{2}$ photocatalyst-mediated damage to viral morphology, rna, and protein. Viruses 2021, 13, 942. [CrossRef]

127. Micochova, P.; Chadha, A.; Hesseloj, T.; Fraternali, F.; Ramsden, J.J.; Gupta, R.K. Rapid inactivation of SARS-CoV-2 by titanium dioxide surface coating. Welcome Open Res. 2021, 6, 56. [CrossRef]

128. Al-Jumaili, A.; Alancherry, S.; Bazaka, K.; Jacob, M.V. Review on the antimicrobial properties of carbon nanostructures. Materials 2017, 10, 1066. [CrossRef]

129. Dai, H.; Liu, X.; Zhang, C.; Ma, K.; Zhang, Y. Electrospinning Polyacrylonitrile/Graphene Oxide/Polyimide nanofibrous membranes for High-efficiency PM2.5 filtration. Sep. Purif Technol. 2021, 276, 119243. [CrossRef]

130. Habibi Mohraz, M.; Je Yu, I.; Beitollahi, A.; Farhang Dehghan, S.; Hoon Shin, J.; Golbabaei, F. Assessment of the potential release of nanomaterials from electrospun nanofiber filter media. NanoImpact 2020, 19, 100223. [CrossRef]

131. Rasmi, Y.; Saloua, K.S.; Nemati, M.; Choi, J.R. Recent progress in nanotechnology for covid-19 prevention, diagnostics and treatment. Nanomaterials 2021, 11, 1788. [CrossRef]

132. Wang, L.; Gao, Y.; Xiong, J.; Shao, W.; Cui, C.; Sun, N.; Zhang, Y.; Chang, S.; Han, P.; Liu, F.; et al. Biodegradable and highperformance multiscale structured nanofiber membrane as mask filter media via poly(lactic acid) electrospinning. J. Colloid Intrfaces Sci. 2021, 606, 961-970. [CrossRef] 
133. Li, Y.; Xiang, Q.; Zhang, Q.; Huang, Y.; Su, Z. Overview on the recent study of antimicrobial peptides: Origins, functions, relative mechanisms and application. Peptides 2012, 37, 207-215. [CrossRef] [PubMed]

134. Onaizi, S.A.; Leong, S.S. Tethering antimicrobial peptides: Current status and potential challenges. Biotech. Adv. 2011, $29,67-74$. [CrossRef]

135. Felgueiras, H.P.; Amorim, M.T. Functionalization of electrospun polymeric wound dressings with antimicrobial peptides. Colloid Surf. Biointerfaces 2017, 156, 133-148. [CrossRef]

136. Ciumac, D.; Gong, H.; Hu, X.; Lu, J.R. Membrane targeting cationic antimicrobial peptides. J. Colloid Interfaces Sci. 2019, 537, 163-185. [CrossRef] [PubMed]

137. Corrêa, J.A.; Evangelista, A.G.; Nazareth, T.M.; Luciano, F.B. Fundamentals on the molecular mechanism of action of antimicrobial peptides. Matarials 2019, 8, 100494.

138. Huan, Y.; Kong, Q.; Mou, H.; Yi, H. Antimicrobial peptides: Classification, design, application and research progress in multiple fields. Front. Microbiol. 2020, 11, 2559. [CrossRef]

139. Yang, J.Q.; Wang, Z.; Wu, J.H.; Hao, L.M.; Tian, T.; Lin, S. Study on an air filter material immobilized with bio-antimicrobials. Adv. Mater. Res. 2011, 152, 1519-1524. [CrossRef] 